\title{
Nitrogen reduction and functionalization by a multimetallic uranium nitride complex
}

\author{
Marta Falcone ${ }^{1}$, Lucile Chatelain ${ }^{1}$, Rosario Scopelliti ${ }^{1}$, Ivica Živković ${ }^{2}$ \& Marinella Mazzanti ${ }^{1}$
}

Molecular nitrogen $\left(\mathrm{N}_{2}\right)$ is cheap and widely available, but its unreactive nature is a challenge when attempting to functionalize it under mild conditions with other widely available substrates (such as carbon monoxide, $\mathrm{CO}$ ) to produce value-added compounds. Biological $\mathrm{N}_{2}$ fixation can do this, but the industrial Haber-Bosch process for ammonia production operates under harsh conditions (450 degrees Celsius and 300 bar), even though both processes are thought to involve multimetallic catalytic sites ${ }^{1,2}$. And although molecular complexes capable of binding and even reducing $\mathrm{N}_{2}$ under mild conditions are known, with co-operativity between metal centres considered crucial for the $\mathrm{N}_{2}$ reduction step ${ }^{1-14}$, the multimetallic species involved are usually not well defined, and further transformation of $\mathrm{N}_{2}$-binding complexes to achieve $\mathrm{N}-\mathrm{H}$ or $\mathrm{N}-\mathrm{C}$ bond formation is rare $\mathrm{r}^{2,6,8,10,15,16}$. Haber noted ${ }^{17}$, before an iron-based catalyst was adopted for the industrial Haber-Bosch process, that uranium and uranium nitride materials are very effective heterogeneous catalysts for ammonia production from $\mathrm{N}_{2}$. However, few examples of uranium complexes binding $\mathrm{N}_{2}$ are known $^{18-22}$, and soluble uranium complexes capable of transforming $\mathrm{N}_{2}$ into ammonia or organonitrogen compounds have not yet been identified. Here we report the four-electron reduction of $\mathrm{N}_{2}$ under ambient conditions by a fully characterized complex with two $\mathrm{U}^{\mathrm{III}}$ ions and three $\mathrm{K}^{+}$centres held together by a nitride group and a flexible metalloligand framework. The addition of $\mathrm{H}_{2}$ and/or protons, or $\mathrm{CO}$ to the resulting $\mathrm{N}_{2}^{4-}$ complex results in the complete cleavage of $\mathrm{N}_{2}$ with concomitant $\mathrm{N}_{2}$ functionalization through $\mathrm{N}-\mathrm{H}$ or $\mathrm{N}-\mathrm{C}$ bond-forming reactions. These observations establish that a molecular uranium complex can promote the stoichiometric transformation of $\mathrm{N}_{2}$ into $\mathrm{NH}_{3}$ or cyanate, and that a flexible, electron-rich, multimetallic, nitride-bridged core unit is a promising starting point for the design of molecular complexes capable of cleaving and functionalizing $\mathrm{N}_{2}$ under mild conditions.

We prepared the diuranium(III) nitride complex $\left[\mathrm{K}_{3}\left\{\left[\mathrm{U}(\mathrm{OR})_{3}\right]_{2}(\mu-\mathrm{N})\right\}\right]$, $\mathbf{1},\left(\mathrm{R}=\mathrm{Si}\left(\mathrm{O}^{t} \mathrm{Bu}\right)_{3}\right)$ by reduction of the previously reported ${ }^{23}$ diurani$\mathrm{um}(\mathrm{IV})$ nitride-bridged complex $\left[\mathrm{Cs}\left\{\left[\mathrm{U}(\mathrm{OR})_{3}\right]_{2}(\mu-\mathrm{N})\right\}\right]$ with excess $\mathrm{KC}_{8}$ (10 equiv.) in THF (tetrahydrofuran) at $-70^{\circ} \mathrm{C}$. The presence of potassium results in greater solid-state and solution stability of complex 1 compared to the previously reported ${ }^{24} \mathrm{Cs}$ analogue $\left[\mathrm{Cs}_{3}\left\{\left[\mathrm{U}(\mathrm{OR})_{3}\right]_{2}(\mu-\mathrm{N})\right\}\right]$ $\left(\mathrm{Cs}_{3} \mathrm{U}-\mathrm{N}-\mathrm{U}\right)$, allowing for more controlled reactivity. The solid-state molecular structure of complex 1 (Fig. 1a) features a heterometallic $\mathrm{K}_{3} \mathrm{U}-\mathrm{N}-\mathrm{U}$ core in which the two uranium(III) are bridged by a nitride group. Three siloxide-ligated $\mathrm{K}^{+}$bind the nitride moiety, forming a distorted triangular array that is perpendicular to the $\mathrm{U}^{\mathrm{III}}-\mathrm{N}-\mathrm{U}^{\mathrm{III}}$ core with a U-N-U angle of $173.7(8)^{\circ}$ and a U-U distance of 4.234(2) A. Overall, the potassium-siloxide framework results in the presence of three flexible bidentate metalloligands bridging the two uranium ions.

Exposing the multimetallic uranium(III) complex 1 to $\mathrm{N}_{2}(0.5-1 \mathrm{~atm})$ at room temperature in the solid state or in a toluene solution affords $\left[\mathrm{K}_{3}\left\{\left[\mathrm{U}(\mathrm{OR})_{3}\right]_{2}(\mu-\mathrm{N})\left(\mu-\eta^{2}: \eta^{2}-\mathrm{N}_{2}\right)\right\}\right], 2$, in $68 \%$ isolated yield (Fig. 2a). The X-ray crystal structure of $\mathbf{2}$ (Fig. 1b) shows one nitrido atom and a side-on-bound hydrazido moiety $\left(\mathrm{N}_{2}^{4-}\right)$ bridging two uranium centres in a diamond-shaped geometry with a U-U distance of 3.305(1) $\AA$. The assignment of the three nitrogen atoms in 2 as a hydrazido(4-) ligand and a nitrido(3-) ligand requires a formal oxidation state of +5 for the uranium ions, which is supported by electron paramagnetic resonance
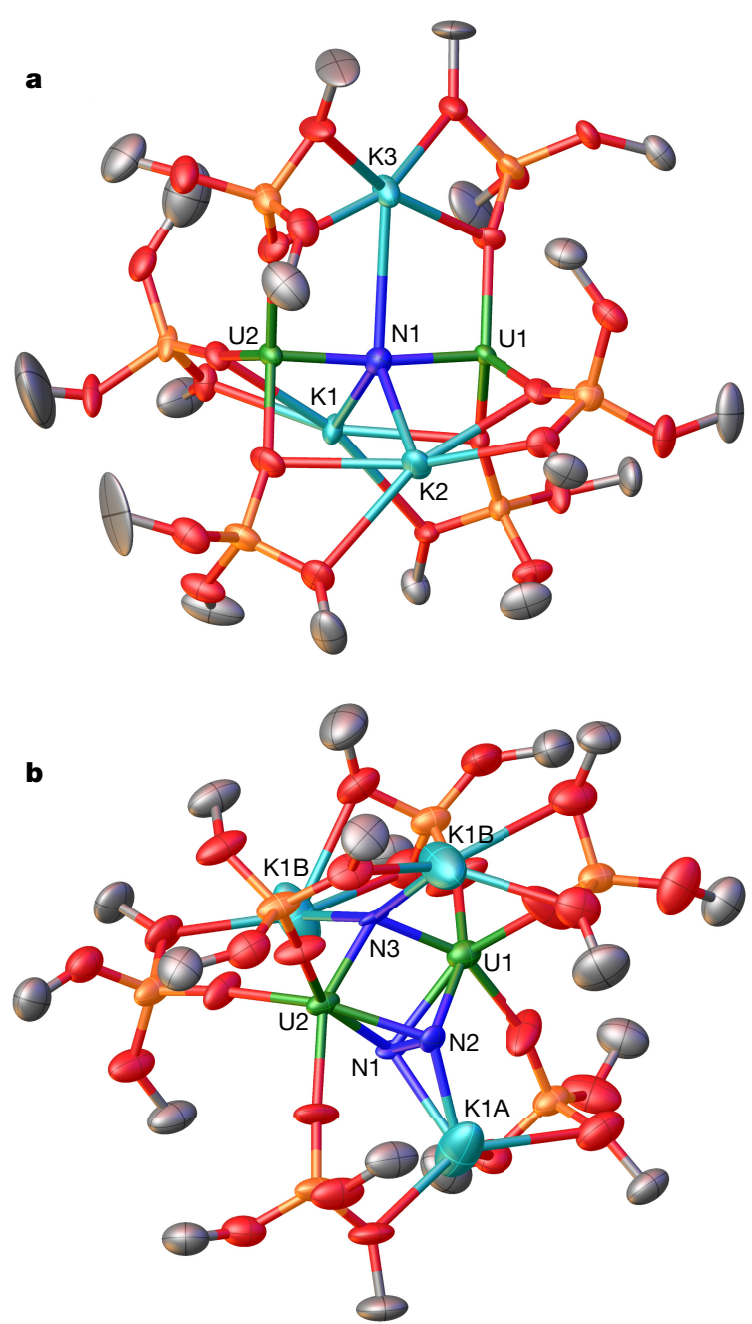

Figure $1 \mid$ Molecular structures of the nitrido and hydrazido complexes. a, Structure of $\left[\mathrm{K}_{3}\left\{\left[\mathrm{U}(\mathrm{OR})_{3}\right]_{2}(\mu-\mathrm{N})\right](\mathbf{1}) ; \mathbf{b}\right.$, structure of $\left[\mathrm{K}_{3}\left\{\left[\mathrm{U}(\mathrm{OR})_{3}\right]_{2}(\mu-\mathrm{N})\right.\right.$ $\left.\left.\left(\mu-\eta^{2}: \eta^{2}-\mathrm{N}_{2}\right)\right\}\right]$ (2). Thermal ellipsoids are depicted at $50 \%$ probability. Methyl groups are omitted for clarity. Only one of the three disordered positions (occupancy of 0.33 ) of the $\mathrm{N}$ atoms in complex $\mathbf{2}$ is shown. Oxygen $(\mathrm{O})$ is shown in red, potassium $(\mathrm{K})$ in sky blue, nitrogen $(\mathrm{N})$ in blue, silicon in orange, carbon in grey, and uranium $(\mathrm{U})$ in green. 


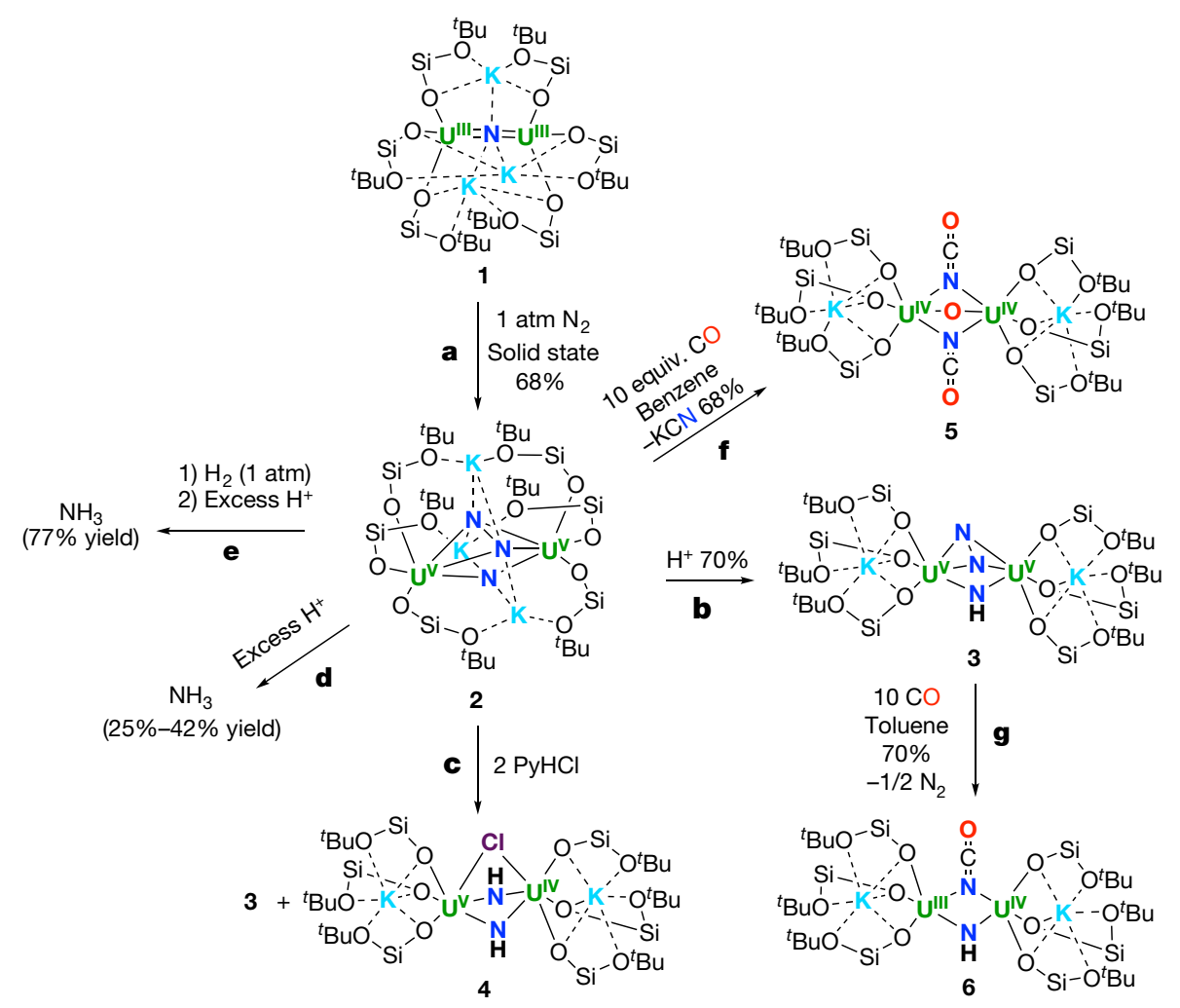

Figure $2 \mid \mathrm{N}_{2}$ reduction and functionalization reactions effected by 1. a, $\mathrm{N}_{2}$ reduction by 1 to afford 2 ; $\mathbf{b}$ and $\mathbf{c}$, protonation reactions of the nitrido and hydrazido ligands in 2 , affording 3 and $\mathbf{4}$, respectively; $\mathbf{d}$, protonation of $\mathbf{2}$ with an excess of acid leads to ammonia formation; e, reaction of 2 with $\mathrm{H}_{2}$ (1 atm) and subsequent addition of an excess of acid affords ammonia; f, reactions of $\mathbf{2}$ with $\mathrm{CO}$ to afford $\mathbf{5} ; \mathbf{g}$, reaction of the imido complex $\mathbf{3}$ with $\mathrm{CO}$ to afford $\mathbf{6}$. In all complexes, only metal-bound $-\mathrm{O}^{t} \mathrm{Bu}$ groups are shown for clarity; yields are given in per cent.

(EPR) data and variable-temperature magnetic data measured with a superconducting quantum interference device (SQUID; see Methods and Extended Data Fig. 1).

Each of the three $\mathrm{N}$ atoms in $\mathbf{2}$ is also bound to a siloxide-ligated potassium cation. The U-N3 distance $(2.069(2) \AA)$ is in the range of $\mathrm{U}-\mathrm{N}$ distances reported for nitride-bridged uranium compounds ${ }^{23,24}$. The $\mathrm{U}_{2}\left(\mu-\eta^{2}: \eta^{2}-\mathrm{N}_{2}\right)$ moiety features $\mathrm{U}-\mathrm{N}$ bond distances ranging from 2.163(13) $\AA$ to 2.311(13) $\AA$, consistent with the presence of U-N single bonds ${ }^{25}$. The value of the N-N bond length (1.521(18) $\AA$ ) corresponds to the presence of a highly activated bound $\mathrm{N}_{2}$ that has been reduced to a hydrazido ${ }^{4-}\left(\mathrm{N}_{2}^{4-}\right)$ moiety. This value is comparable to the observed bond length in hydrazine, $\mathrm{H}_{2} \mathrm{NNH}_{2}(1.47 \AA)$ and falls in the range of values $(1.377(3)-1.635(5) \AA)$ reported for hydrazido complexes $3,6,7,9,14$.

The flexible potassium-siloxide framework plays a crucial role in holding together the U-N-U core while it bends upon $\mathrm{N}_{2}$ binding (the $\mathrm{U}-\mathrm{N}-\mathrm{U}$ angle changes from $173.7(8)^{\circ}$ in $\mathbf{1}$ to $106.0(5)^{\circ}$ in 2$)$. Notably, the different metallo-ligand framework provided by the caesium cation in $\mathrm{Cs}_{3} \mathrm{U}-\mathrm{N}-\mathrm{U}$ does not lead to well defined reactivity. $\mathrm{Cs}_{3} \mathrm{U}-\mathrm{N}-\mathrm{U}$ also reacts with $\mathrm{N}_{2}$ under ambient conditions but the isolation of the reaction products was not successful owing to the concomitant formation of decomposition products. The identity of the specific alkali ion is ordinarily not critical, but a crucial effect of the nature of the cation has been recently shown in models of the iron-based Haber-Bosch process ${ }^{26}$ and in models of the oxygen-evolving complex (OEC) ${ }^{27}$.

The few $\mathrm{N}_{2}$-binding uranium complexes reported to date are, with one exception $^{21}$, all dinuclear complexes with a side-on bridging $\mathrm{N}_{2}$ (where the $\mathrm{N}-\mathrm{N}$ distance remains essentially the same as found in free $\left.\mathrm{N}_{2}\right)^{22}$ or with a side-on bridging $\mathrm{N}_{2}^{2-}$ moiety resulting from the two-electron reduction of $\mathrm{N}_{2}$ by mononuclear complexes of uranium(III) (each complex transferring one electron $)^{18-20}$. We also note that uranium complexes containing the highly activated hydrazido moiety have not been reported so far. Moreover, no information on the reactivity of the dinitrogen in $\mathrm{N}_{2}$-bound uranium complexes has been reported to date, probably owing to the lability of the bound $\mathrm{N}_{2}$ in the previously characterized complexes.

Treating 2 with 1 equiv. of 2,4,6-tri-tert-butylphenol (Fig. 2b) gives the mono-protonated compound $\left[\mathrm{K}_{2}\left\{\left[\mathrm{U}(\mathrm{OR})_{3}\right]_{2}(\mu-\mathrm{NH})\right.\right.$ $\left.\left.\left(\mu-\eta^{2}: \eta^{2}-\mathrm{N}_{2}\right)\right\}\right], \mathbf{3}$, in $70 \%$ yield. The molecular structure of $\mathbf{3}$ (Fig. 3a) shows two $\left[\mathrm{K}\left\{\mathrm{U}(\mathrm{OR})_{3}\right\}\right]$ fragments bridged by an $\mathrm{NH}^{2-}$ ligand and an $\mathrm{N}_{2}^{4-}$ ligand. The geometry of the diamond-shaped $\mathrm{U}_{2} \mathrm{~N}_{3}$ core remains similar to that found in complex 2 , with essentially unchanged U-N distances in the $\mathrm{U}-\mathrm{N}_{2}^{4-}$ fragment. The mean value of the U-N3 distances $(2.11(5) \AA)$ is longer than that found in the nitride-bridged complex $2(2.069(2) \AA)$, and is consistent with the presence of a $U^{v}$ imido-bridged species ${ }^{25}$. Addition of the stronger acids $\mathrm{PyHCl}, \mathrm{HCl}$ or $\mathrm{HBAr}^{\mathrm{F}}\left(\mathrm{BAr}^{\mathrm{F}}=\left[\left\{3,5-\left(\mathrm{CF}_{3}\right)_{2} \mathrm{C}_{6} \mathrm{H}_{3}\right\}_{4} \mathrm{~B}\right]^{-}\right)$to 2 results also in the protonation of the hydrazido ligand (Fig. $2 \mathrm{c}$ and Extended Data Fig. 2), with addition of two equivalents of $\mathrm{PyHCl}$ enabling isolation of a few single crystals of a doubly protonated species with structural parameters consistent with the presence of the bis(imido)-bridged diuranium(IV/v) complex, $\left[\mathrm{K}_{2}\left\{\left[\mathrm{U}\left(\mathrm{OSi}\left(\mathrm{O}^{t} \mathrm{Bu}\right)_{3}\right)_{3}\right]_{2}(\mu-\mathrm{NH})_{2}(\mu-\mathrm{Cl})\right\}\right], 4$ (Fig. 3b).

Adding excess $\mathrm{PyHCl}(20$ equiv.) to complex 2 led to the formation of a precipitate, the ${ }^{1} \mathrm{H}$ NMR spectrum of which (in deuterated DMSO, dimethyl sulfoxide- $\left.\mathrm{d}_{6}\right)$ shows ammonium chloride $\left({ }^{14} \mathrm{NH}_{4} \mathrm{Cl}\right)$ as the only product (Extended Data Fig. 3a). This result and the isolation of complex 4 suggest that the protonation of complex 2 leads to complete cleavage of dinitrogen. The same experiment with the ${ }^{15} \mathrm{~N}$-labelled complex ${ }^{15} \mathrm{~N}-2$ gave a ${ }^{1} \mathrm{H}$ NMR spectrum with signals assigned to ${ }^{15} \mathrm{NH}_{4} \mathrm{Cl}$ (doublet) and ${ }^{14} \mathrm{NH}_{4} \mathrm{Cl}$ (triplet) in a ratio of 1:0.85 (Extended Data Fig. 3b). The addition of excess $\mathrm{HBAr}^{\mathrm{F}}, \mathrm{PyHCl}$ or $\mathrm{HCl}$ to complex 2 resulted in overall yields of ammonia of 25\%, 35\% and 42\% (Fig. 2d), respectively (determined by quantitative NMR spectroscopy, shown in Extended Data Fig. 3c, and indophenol titration, considering a yield of $100 \%$ to be when 1 equiv. of complex 2 gives 3 equiv. of $\mathrm{NH}_{3}$ ). The low ammonia yield could reflect hydrazine disproportionation to form $\mathrm{N}_{2}$.

Because direct hydrogenation of $\mathrm{N}_{2}$ with hydrogen $\left(\mathrm{H}_{2}\right)$ under mild conditions is desirable, yet has been observed only for a few $\mathrm{N}_{2}$ complexes ${ }^{7,9}$, we also explored functionalizing the bound $\mathrm{N}_{2}$ in complex 2 with $\mathrm{H}_{2}$. Letting 2 stand under $\mathrm{H}_{2}$ (1 atm) at room temperature slowly consumes the complex over two to three weeks. The ${ }^{1} \mathrm{H}$ NMR spectrum of the final reaction mixture shows only the presence of the free ligand ( $10 \%$ yield), and no $\mathrm{NH}_{3}$ is observed among the volatiles (Extended Data Fig. 4a). However, adding a solution of $\mathrm{HCl}$ in ether to the product of the reaction of 2 with $\mathrm{H}_{2}$ leads to formation of ammonia in $77 \%$ 

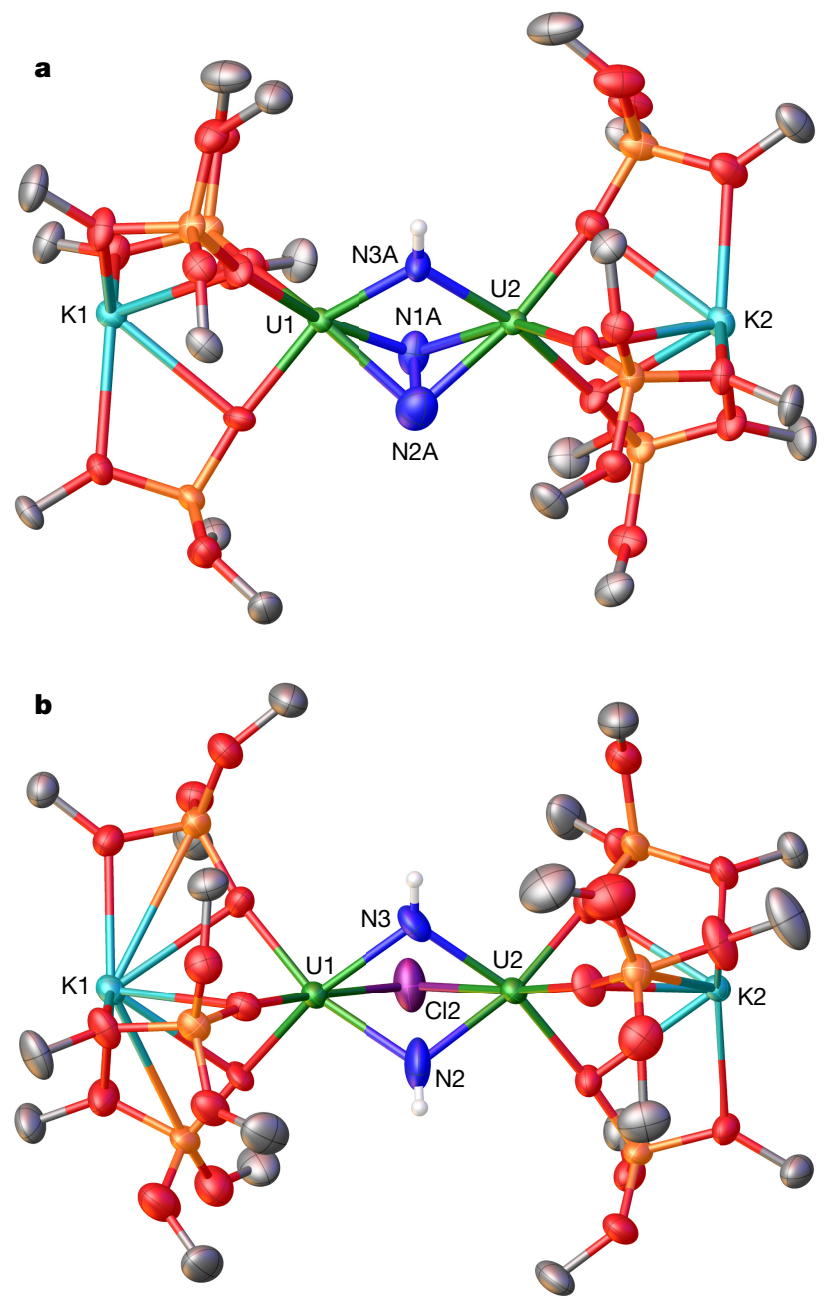

Figure 3 Molecular structures of 3 and 4 . a, $\left[\mathrm{K}_{2}\left\{\left[\mathrm{U}\left(\mathrm{OSi}\left(\mathrm{O}^{t} \mathrm{Bu}\right)_{3}\right)_{3}\right]_{2}(\mu-\mathrm{NH})\right.\right.$ $\left.\left.\left(\mu-\eta^{2}: \eta^{2}-\mathrm{N}_{2}\right)\right\}\right](\mathbf{3})$; b complex $\left[\mathrm{K}_{2}\left\{\left[\mathrm{U}\left(\mathrm{OSi}\left(\mathrm{O}^{t} \mathrm{Bu}\right)_{3}\right)_{3}\right]_{2}(\mu-\mathrm{NH})_{2}(\mu-\mathrm{Cl})\right\}\right](4)$. Thermal ellipsoids are depicted at 50\% probability. Methyl groups are omitted for clarity. Only one of the two disordered positions of the $\mathrm{N}$ atoms (and $\mathrm{Cl}$ atoms for $\mathbf{4}$ ) is shown for complexes $\mathbf{3}$ and $\mathbf{4}$. Chlorine $(\mathrm{Cl})$ is shown in purple, hydrogen is shown in white, and other colours as in Fig. 1.

yield (Fig. 2e and Extended Data Fig. 4b). Adding a solution of $\mathrm{HCl}$ in ether to the product of the reaction of ${ }^{15} \mathrm{~N}-2$ with $\mathrm{H}_{2}$ leads to the formation of ${ }^{15} \mathrm{NH}_{4} \mathrm{Cl}$ and ${ }^{14} \mathrm{NH}_{4} \mathrm{Cl}$ (giving a doublet and a triplet signal, respectively, in the ${ }^{1} \mathrm{H}$ NMR spectrum) in a 2:1 ratio, indicating that the three nitrogen atoms are all incorporated in the ammonia generated (Extended Data Fig. 4c).

Complex 2 also reacts with CO (10 equiv.) in THF or benzene at room temperature to afford the $\mathrm{U}^{\mathrm{IV}} / \mathrm{U}^{\mathrm{IV}}$ oxo/cyanate complex $\left[\mathrm{K}_{2}\left\{\left[\mathrm{U}(\mathrm{OR})_{3}\right]_{2}(\mu-\mathrm{O})(\mu-\mathrm{NCO})_{2}\right\}\right], \mathbf{5}$, which was isolated by recrystallization from THF in 68\% yield (Fig. $2 \mathrm{f}$ and Extended Data Fig. $5 \mathrm{a}$ and b). Elemental analysis supports the assignment of $\mathbf{5}$ as an oxo/cyanate complex, an assignment further corroborated by the formation of $\mathrm{CN}^{-}$ as a by-product detected by ${ }^{13} \mathrm{C}$ NMR (Extended Data Fig. $5 \mathrm{c}$ ). The X-ray crystal structure of complex 5 (Fig. 4a) shows two $\left[\mathrm{K}\left\{\mathrm{U}(\mathrm{OR})_{3}\right\}\right]$ fragments bridged by an oxo group $\left(\mathrm{O}^{2-}\right)$ and two cyanate $\left(\mathrm{OCN}^{-}\right)$ moieties in a bent geometry, with a $\mathrm{U} 1-\mathrm{O}-\mathrm{U} 2$ angle of $108.7(3)^{\circ}$ and $\mathrm{U}-\mathrm{N}_{\text {cyanate }}-\mathrm{U}$ angles of $88.0(3)^{\circ}$ and $89.0(3)^{\circ}$. The nitride and the hydrazido ligands thus both react with $\mathrm{CO}$, so that successive reaction of the nitride-bridged diuranium(III) complex 1 with $\mathrm{N}_{2}$ and $\mathrm{CO}$ leads to $\mathrm{N}_{2}$ cleavage and functionalization by a well-defined uranium complex. The nucleophilic addition of the nitride to $\mathrm{CO}$ results in the complete cleavage of the $\mathrm{CO}$ triple bond, leading to the formation of a bridging oxo complex and cyanide $\left(\mathrm{CN}^{-}\right)$that is extruded as $\mathrm{KCN}$.
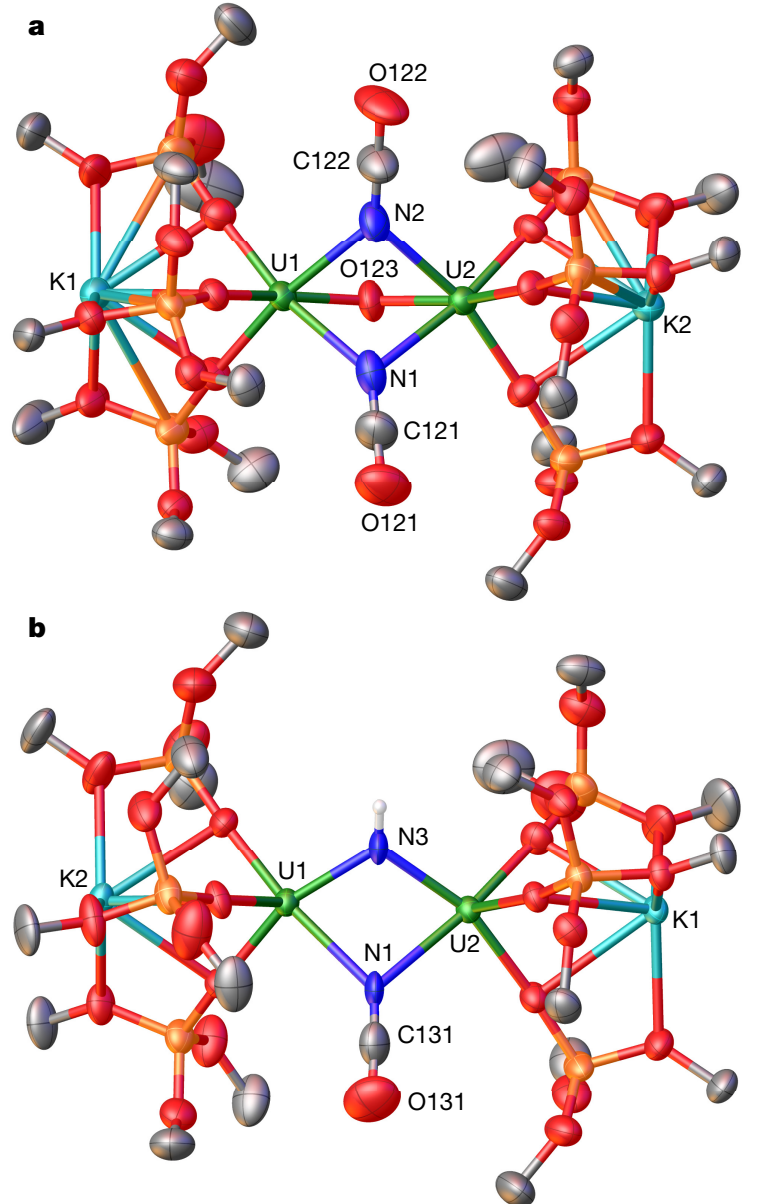

Figure $4 \mid$ Molecular structures of 5 and $6 . \mathbf{a},\left[\mathrm{K}_{2}\left\{\left[\mathrm{U}\left(\mathrm{OSi}\left(\mathrm{O}^{t} \mathrm{Bu}\right)_{3}\right)_{3}\right]_{2}(\mu-\mathrm{O})\right.\right.$ $\left.\left.(\mu-\mathrm{NCO})_{2}\right\}\right](\mathbf{5})$; b, $\left[\mathrm{K}_{2}\left\{\left[\mathrm{U}\left(\mathrm{OSi}\left(\mathrm{O}^{t} \mathrm{Bu}\right)_{3}\right)_{3}\right]_{2}(\mu-\mathrm{NH})(\mu-\mathrm{NCO})\right\}\right](\mathbf{6})$. Thermal ellipsoids are depicted at 50\% probability. Methyl groups are omitted for clarity. Only one of the two disordered positions of the NCO ligand is shown in complex 6. Colours as in Fig. 1.

We have recently reported similar reactivity for the nitride-bridged diuranium(IV) complex, $\left[\mathrm{Cs}\left\{\left[\mathrm{U}(\mathrm{OR})_{3}\right]_{2}(\mu-\mathrm{N})\right\}\right]$, which completely cleaves the $\mathrm{CO}$ triple bond under ambient conditions to yield the oxo/ cyanide diuranium(Iv) complex, $\left[\mathrm{Cs}\left\{\left[\mathrm{U}(\mathrm{OR})_{3}\right]_{2}(\mu-\mathrm{CN})(\mu-\mathrm{O})\right\}\right]^{28}$. The reductive carbonylation of uranium(v) and uranium(vi) terminal nitrides to afford cyanate has also been reported ${ }^{29}$, but reductive carbonylation of metal dinitrogen complexes is unprecedented. Ligandinduced cleavage of dinitrogen has been achieved with $\mathrm{Zr}^{\mathrm{IV}}$ and $\mathrm{Hf}^{\mathrm{IV}}$ metallocene complexes, but differs from the reactivity of $\mathbf{2}$ in that addition of excess $\mathrm{CO}(1-4 \mathrm{~atm})$ to the reduced $\mathrm{N}_{2}^{4-}$ in $\mathrm{Zr}^{\mathrm{IV}}$ and $\mathrm{Hf}^{\mathrm{gV}}$ metallocene complexes affords the $\left[\mathrm{N}_{2} \mathrm{C}_{2} \mathrm{O}_{2}\right]^{4-}$ (oxamidide) fragment and does not involve metal-centred electron transfer ${ }^{10,30}$.

The high reactivity of both the nitride and the hydrazido ligands in complex 2 with CO renders it difficult to envisage a possible synthetic cycle that would allow for the transformation of $\mathrm{N}_{2}$ and $\mathrm{CO}$ into cyanate and then restore the $\mathrm{U}^{\mathrm{III}}-\mathrm{N}-\mathrm{U}^{\mathrm{III}}$ precursor.

Anticipating reduced reactivity of the protonated nitride group with $\mathrm{CO}$, we explored the reactivity of complex 3 , and found that addition of $\mathrm{CO}$ (10 equiv.) to a toluene solution of $\mathbf{3}$ and standing for $24 \mathrm{~h}$ at room temperature gave brown crystals of the cyanate complex, $\left[\mathrm{K}_{2}\left\{\left[\mathrm{U}(\mathrm{OR})_{3}\right]_{2}(\mu-\mathrm{NH})(\mu-\mathrm{NCO})\right\}\right], 6$, in $70 \%$ yield (Fig. $2 \mathrm{~g}$ and Extended Data Fig. $6 \mathrm{a}$ and $\mathrm{b})$. The high yield suggests that the $\mathrm{U}^{\mathrm{III}} / \mathrm{U}^{\mathrm{IV}}$ complex 6 is the major uranium species formed in this reaction. The ${ }^{13} \mathrm{C} \mathrm{NMR}$ spectrum of the reaction mixture of $\mathbf{3}$ with ${ }^{13} \mathrm{CO}$ in deuterated water does not show free $\mathrm{HN}^{13} \mathrm{CO}$ or ${ }^{13} \mathrm{CN}^{-}$(Extended Data Fig. 6c). The stoichiometry and the electron balance of the reductive carbonylation of $\mathbf{3}$ require the concomitant elimination of dinitrogen. Analysis of the 
headspace from the reaction of ${ }^{15} \mathrm{~N}-3$ with CO by GC-MS (gas chromatography mass spectrometry) analysis confirmed the presence of ${ }^{15} \mathrm{~N}_{2}$ and ${ }^{14} \mathrm{~N}^{15} \mathrm{~N}$ at mass to charge ratios $m / z=30$ and $m / z=29$ respectively (Extended Data Fig. 6d).

The X-ray crystal structure of $\mathbf{6}$ (Fig. 4b) is consistent with a mixed-valent $\mathrm{U}^{\mathrm{III}} / \mathrm{U}^{\mathrm{IV}}$ complex, with one imido $\left(\mathrm{NH}^{2-}\right)$ group and one cyanate $\left(\mathrm{NCO}^{-}\right)$group (disordered over two crystallographic positions) bridging the two uranium centres in a non-planar diamond-shaped geometry. The mean value of the U-NH distance $(2.18(3) \AA)$ is longer than in complex $3(2.10(5) \AA)$, in agreement with the presence of a uranium(III) centre.

The observed difference in reactivity between complex 2 and 3 is probably due to replacement of $\mathrm{N}^{3-}$ with a less electron donating $\mathrm{NH}^{2-}$ group, which enables $\mathrm{U}^{\mathrm{V}}$ reduction to $\mathrm{U}^{\mathrm{III}}$. Preliminary attempts to reduce complex 6 to regenerate the diuranium ${ }^{\text {III }}$ precursor have not been successful, and future studies will focus on the identification of possible synthetic cycles allowing the production of cyanate from $\mathrm{N}_{2}$ and $\mathrm{CO}$.

Bimetallic complexes containing highly activated side-on-bound dinitrogen $\left(\mathrm{N}_{2}^{4-}\right)$ that can be further reduced and completely cleaved by the addition of reducing ligands such as $\mathrm{H}_{2}$ or $\mathrm{CO}$ have so far only been reported for group 4 metals $s^{6,7,9,10,14}$. In these systems, the intermediate species (probably dinuclear $\mathrm{Zr}^{\mathrm{II}}$ and $\mathrm{Hf}^{\mathrm{II}}$ complexes) involved in $\mathrm{N}_{2}$ activation were prepared by in situ reduction of mononuclear $\mathrm{M}^{\mathrm{IV}}$ complexes under a $\mathrm{N}_{2}$ atmosphere and not characterized. Ligandinduced $\mathrm{N}_{2}$ cleavage in these systems also differs from the reactivity of 2 and $\mathbf{3}$ in that no metal-centred electron transfer is involved ${ }^{9,10}$, while the reaction of the $\left(\mathrm{U}-\left(\mathrm{N}_{2}\right)^{4-}\right)$ complex with $\mathrm{CO}$ that we report confirms uranium-centred electron transfer that yields different reaction products from those obtained with the group 4 metals.

We also note that the higher redox flexibility of uranium makes it well positioned for the implementation of catalytic N-C bondforming cycles that exploit the assembly of low-valent metals and alkali ions through bridging nitrides as an optimized arrangement for the cooperative binding and activation of dinitrogen; the stable yet flexible U-N-U core can bend to accommodate the $\mathrm{N}_{2}$ moiety. We envisage that these design principles could also be extended to other metals, provided that the corresponding low-valent nitride complex can be stabilized, and thereby aid the development of new molecular systems for the catalytic transformation of $\mathrm{N}_{2}$.

Online Content Methods, along with any additional Extended Data display items and Source Data, are available in the online version of the paper; references unique to these sections appear only in the online paper.

Received 19 November 2016; accepted 7 June 2017.

1. MacKay, B. A. \& Fryzuk, M. D. Dinitrogen coordination chemistry: on the biomimetic borderlands. Chem. Rev. 104, 385-401 (2004).

2. MacLeod, K. C. \& Holland, P. L. Recent developments in the homogeneous reduction of dinitrogen by molybdenum and iron. Nat. Chem. 5, 559-565 (2013).

3. Gambarotta, S. \& Scott, J. Multimetallic cooperative activation of $\mathrm{N}_{2}$. Angew. Chem. Int. Edn Engl. 43, 5298-5308 (2004).

4. McWilliams, S. F. \& Holland, P. L. Dinitrogen binding and cleavage by multinuclear iron complexes. Acc. Chem. Res. 48, 2059-2065 (2015).

5. Laplaza, C. E. \& Cummins, C. C. Dinitrogen cleavage by a three-coordinate molybdenum(III). Science 268, 861-863 (1995).

6. Ohki, Y. \& Fryzuk, M. D. Dinitrogen activation by group 4 metal complexes. Angew. Chem. Int. Edn Engl. 46, 3180-3183 (2007).

7. Pool, J. A., Lobkovsky, E. \& Chirik, P. J. Hydrogenation and cleavage of dinitrogen to ammonia with a zirconium complex. Nature 427, 527-530 (2004).

8. Rodriguez, M. M., Bill, E., Brennessel, W. W. \& Holland, P. L. N ${ }_{2}$ reduction and hydrogenation to ammonia by a molecular iron-potassium complex. Science 334, 780-783 (2011).

9. Fryzuk, M. D., Love, J. B., Rettig, S. J. \& Young, V. G. Transformation of coordinated dinitrogen by reaction with dihydrogen and primary silanes. Science 275, 1445-1447 (1997).

10. Knobloch, D. J., Lobkovsky, E. \& Chirik, P. J. Dinitrogen cleavage and functionalization by carbon monoxide promoted by a hafnium complex. Nat. Chem. 2, 30-35 (2010).
11. Arashiba, K., Miyake, Y. \& Nishibayashi, Y. A molybdenum complex bearing PNP-type pincer ligands leads to the catalytic reduction of dinitrogen into ammonia. Nat. Chem. 3, 120-125 (2011)

12. Evans, W. J. et al. Isolation of dysprosium and yttrium complexes of a three-electron reduction product in the activation of dinitrogen, the $\left(\mathrm{N}_{2}\right)^{3-}$ radical. J. Am. Chem. Soc. 131, 11195-11202 (2009).

13. Lee, Y. et al. Dinitrogen activation upon reduction of a triiron(II) complex. Angew. Chem. Int. Edn Engl. 54, 1499-1503 (2015).

14. Hirotsu, M., Fontaine, P. P., Zavalii, P. Y. \& Sita, L. R. Extreme $\mathrm{N} \equiv \mathrm{N}$ bond elongation and facile $\mathrm{N}$-atom functionalization reactions within two structurally versatile new families of group 4 bimetallic "side-on-bridged" dinitrogen complexes for zirconium and hafnium. J. Am. Chem. Soc. 129, 12690-12692 (2007)

15. Spencer, L. P., MacKay, B. A., Patrick, B. O. \& Fryzuk, M. D. Inner-sphere two-electron reduction leads to cleavage and functionalization of coordinated dinitrogen. Proc. Natl Acad. Sci. USA 103, 17094-17098 (2006).

16. Nishibayashi, $Y$. Recent progress in transition-metal-catalyzed reduction of molecular dinitrogen under ambient reaction conditions. Inorg. Chem. 54, 9234-9247 (2015)

17. Haber, F. Verfahren zur Herstellung von Ammoniak durch katalytische Vereinigung von Stickstoff und Wasserstoff, zweckmäßig unter hohem Druch. German patent DE 229126 (1909)

18. Cloke, G. F. N. \& Hitchcock, P. B. Reversible binding and reduction of dinitrogen by a uranium(III) pentalene complex. J. Am. Chem. Soc. 124, 9352-9353 (2002).

19. Odom, A. L., Arnold, P. L. \& Cummins, C. C. Heterodinuclear uranium/ molybdenum dinitrogen complexes. J. Am. Chem. Soc. 120, 5836-5837 (1998).

20. Mansell, S. M., Kaltsoyannis, N. \& Arnold, P. L. Small molecule activation by uranium tris(aryloxides): experimental and computational studies of binding of $\mathrm{N}_{2}$, coupling of $\mathrm{CO}$, and deoxygenation insertion of $\mathrm{CO}_{2}$ under ambient conditions. J. Am. Chem. Soc. 133, 9036-9051 (2011).

21. Evans, W. J., Kozimor, S. A. \& Ziller, J. W. A monometallic f element complex of dinitrogen: $\left(\mathrm{C}_{5} \mathrm{Me}_{5}\right)_{3} \mathrm{U}\left(\eta^{1}-\mathrm{N}_{2}\right)$. J. Am. Chem. Soc. 125, 14264-14265 (2003).

22. Roussel, P. \& Scott, P. Complex of dinitrogen with trivalent uranium. J. Am. Chem. Soc. 120, 1070-1071 (1998).

23. Camp, C., Pecaut, J. \& Mazzanti, M. Tuning uranium-nitrogen multiple bond formation with ancillary siloxide ligands. J. Am. Chem. Soc. 135, 12101-12111 (2013)

24. Chatelain, L., Scopelliti, R. \& Mazzanti, M. Synthesis and structure of nitride-bridged uranium(III) complexes. J. Am. Chem. Soc. 138, 1784-1787 (2016)

25. Spencer, L. P. et al. Cation-cation interactions, magnetic communication, and reactivity of the pentavalent uranium ion $\left[\mathrm{U}\left(\mathrm{N}^{\mathrm{t} B u}\right)_{2}\right]^{+}$. Angew. Chem. Int. Edn Engl. 48, 3795-3798 (2009).

26. Grubel, K., Brennessel, W. W., Mercado, B. Q. \& Holland, P. L. Alkali metal control over N-N cleavage in iron complexes. J. Am. Chem. Soc. 136, 16807-16816 (2014).

27. Tsui, E. Y., Tran, R., Yano, J. \& Agapie, T. Redox-inactive metals modulate the reduction potential in heterometallic manganese-oxido clusters. Nat. Chem. $\mathbf{5}$, 293-299 (2013).

28. Falcone, M., Kefalidis, C. E., Scopelliti, R., Maron, L. \& Mazzanti, M. Facile CO cleavage by a multimetallic $\mathrm{CsU}_{2}$ nitride complex. Angew. Chem. Int. Edn Engl. 55, 12290-12294 (2016).

29. Cleaves, P. A. et al. Two-electron reductive carbonylation of terminal uranium(V) and uranium(VI) nitrides to cyanate by carbon monoxide. Angew. Chem. Int. Edn Engl. 53, 10412-10415 (2014).

30. Knobloch, D. J., Lobkovsky, E. \& Chirik, P. J. Carbon monoxide-induced dinitrogen cleavage with group 4 metallocenes: reaction scope and coupling to $\mathrm{N}-\mathrm{H}$ bond formation and $\mathrm{CO}$ deoxygenation. J. Am. Chem. Soc. 132, 10553-10564 (2010).

Acknowledgements We acknowledge support from the Swiss National Science Foundation (200021-157158 and 200021-162430) and from the Ecole Polytechnique Fédérale de Lausanne (EPFL). We thank E. Solari for carrying out the elemental analyses, and D. Kubicky (of the L. Emsley group) for assistance with EPR measurements, M. Prevot (of the K. Sivula group) for assistance with Raman and B. Rozmyslowicz (of the J. Luterbacher group) for assistance with IR and GC-MS measurements. We thank F. F. Tirani for her contribution to the X-ray single crystal structure analyses.

Author Contributions M.F. carried out the synthetic experiments and analysed the experimental data; L.C. carried out preliminary synthetic experiments, including the isolation of the dinitrogen complex. R.S. performed the X-ray single crystal structure analyses; I.Z. carried out and analysed the magnetic measurements; M.M. and M.F. wrote the manuscript. M.M. originated the central idea, coordinated the work and analysed the experimental data.

Author Information Reprints and permissions information is available at www.nature.com/reprints. The authors declare no competing financial interests. Readers are welcome to comment on the online version of the paper. Publisher's note: Springer Nature remains neutral with regard to jurisdictional claims in published maps and institutional affiliations. Correspondence and requests for materials should be addressed to M.M. (marinella.mazzanti@epfl.ch). 


\section{METHODS}

Materials. Unless otherwise noted, reagents were purchased from commercial suppliers and used without further purification. Tris(tert-butoxy)silanol and 2,4,6-tri-tert-butylphenol were purified by sublimation. The solvents were purchased from Aldrich or Cortecnet (deuterated solvents) in their anhydrous form, conditioned under argon and vacuum distilled from $\mathrm{K} / \mathrm{benzophenone}$ (toluene, THF, benzene- $\mathrm{d}_{6}$ and $n$-hexane). DMSO- $\mathrm{d}_{6}$ was freeze-degassed and stored over activated $3 \AA$ molecular sieves. The complexes $\left[\mathrm{Cs}\left\{\left[\mathrm{U}(\mathrm{OR})_{3}\right]_{2}(\mu-\mathrm{N})\right\}\right]^{23}$ $\left(\mathrm{R}=\mathrm{Si}\left(\mathrm{O}^{t} \mathrm{Bu}\right)_{3}\right)$ and $\left[\mathrm{Cs}_{3}\left\{\left[\mathrm{U}(\mathrm{OR})_{3}\right]_{2}(\mu-\mathrm{N})\right\}\right]^{24}$ were prepared according to published procedure. Carbon monoxide (N47 Bt-S 10/200) was purchased from Carbagas and stored over activated $3 \AA$ molecular sieves. Depleted uranium was purchased from IBILABS, USA. $\mathrm{N}_{2}$ (99.9999\% purity) and $\mathrm{H}_{2}$ (99.9999\% purity) were purchased from Carbagas. ${ }^{13} \mathrm{CO}\left(93.13 \%{ }^{13} \mathrm{C}\right)$ and ${ }^{15} \mathrm{~N}_{2}\left(98 \%{ }^{15} \mathrm{~N}\right)$ were purchased from Cortecnet and stored over activated $3 \AA$ molecular sieves. All manipulations were carried out under a dry and oxygen-free argon atmosphere using Schlenk techniques and an MBraun glovebox equipped with a purifier unit. The water and oxygen levels were always kept at less than 0.1 p.p.m. Glassware was dried overnight at $140^{\circ} \mathrm{C}$ before use.

Caution: Depleted uranium (primary isotope ${ }^{238} \mathrm{U}$ ) is a weak $\alpha$-emitter $(4.197 \mathrm{MeV})$ with a half-life of $4.47 \times 10^{9}$ years. Manipulations and reactions should be carried out in monitored fume hoods or in an inert atmosphere glovebox in a radiation laboratory equipped with $\alpha$ - and $\beta$-counting equipment.

${ }^{1} \mathrm{H}$ NMR experiments. ${ }^{1} \mathrm{H}$ NMR experiments were carried out using NMR tubes adapted with J. Young valves. ${ }^{1} \mathrm{H}$ NMR spectra were recorded on a Bruker $400 \mathrm{MHz}$ spectrometer. NMR chemical shifts are reported in p.p.m. with solvent as internal reference.

Elemental analyses. CHN elemental microanalyses were obtained using a Thermo Scientific Flash 2000 Organic Elemental Analyzer at the Institute of Chemistry and Chemical Engineering at EPFL.

Infrared analyses. Infrared analyses were performed with a Spectrum One FT-IR Spectrometer (Perkin-Elmer); the measurement for complex $\mathbf{6}$ was performed with a Perkin Elmer Frontier FT-IR equipped with a liquid nitrogen cooled MCT detector. The sample was placed into a Harrick High Temperature Chamber DRIFT cell under argon atmosphere. Scans were performed in a range between $400 \mathrm{~cm}^{-1}$ and $4,000 \mathrm{~cm}^{-1}$ at a resolution of $4 \mathrm{~cm}^{-1}$

Raman analysis. Raman analysis was performed with a XploRA PLUS Raman microscope from Jobin Yvon Horiba. Excitation line was provided by an Ar laser $(532.19 \mathrm{~nm})$.

GC-MS analysis. GC-MS analysis of headspace from the reaction of ${ }^{15} \mathrm{~N}-3$ with CO was performed under argon using an Agilent 7890B GC equipped with an HP-5MS UI column $(60 \mathrm{~m} \times 0.25 \mathrm{~mm} \times 0.25 \mu \mathrm{m})$ coupled to an MS detector. The reaction was conducted in a $1 \mathrm{ml}$ vial equipped with a J. Young valve, and the pressure was equilibrated with argon at the end of the reaction. The headspace was recovered with a syringe from a septum adapted on the J. Young valve and immediately injected into the instrument. The analysis method used was $0.5 \mathrm{ml}$ injection of sample, injection temperature of $250^{\circ} \mathrm{C}, 5: 1$ split ratio, initial inlet pressure was $9.1 \mathrm{psi}$, but varied as the column flow was held constant at $1.2 \mathrm{ml} \mathrm{min}^{-1}$ for the duration of the run, the interface temperature was held at $280^{\circ} \mathrm{C}$, and the ion source (EI, $70 \mathrm{eV}$ ) was held at $230^{\circ} \mathrm{C}$. Scan range was set to $13-41 \mathrm{~m} / \mathrm{z}$, with a step size of $0.1 \mathrm{~m} / z$. The oven temperature was initially held at $40^{\circ} \mathrm{C}$ for $5 \mathrm{~min}$ followed by a temperature ramp to $150^{\circ} \mathrm{C}$ at $15^{\circ} \mathrm{C} \mathrm{min}^{-1}$.

Synthesis of $\left[\mathrm{K}_{3}\left\{\left[\mathrm{U}(\mathrm{OR})_{3}\right]_{2}(\mu-\mathrm{N})\right\}\right]$, compound 1 (Extended Data Fig. 7a). A cold $\left(-70^{\circ} \mathrm{C}\right)$ red-brown solution of $\left[\mathrm{Cs}\left\{\left[\mathrm{U}(\mathrm{OR})_{3}\right]_{2}(\mu-\mathrm{N})\right\}\right](223.2 \mathrm{mg}, 0.101 \mathrm{mmol}, 1$ equiv.) in THF $(2.0 \mathrm{ml})$ was added onto cold $\left(-70^{\circ} \mathrm{C}\right) \mathrm{KC}_{8}(136.8 \mathrm{mg}, 1.01 \mathrm{mmol}$, 10 equiv.) under argon. After $5 \mathrm{~min}$ stirring at $-70^{\circ} \mathrm{C}$, the resulting dark purple suspension was evaporated while maintaining the reaction flask at a cold temperature, and the resulting residue was extracted with $1 \mathrm{ml}$ of cold $n$-hexane. The resulting suspension was filtered at $-70^{\circ} \mathrm{C}$ to remove the excess of $\mathrm{KC}_{8}$ and graphite, which were then washed with cold $n$-hexane $(30 \mathrm{ml})$. The filtrate was concentrated ( $1 \mathrm{ml})$. After $4 \mathrm{~h}$ at $-70^{\circ} \mathrm{C}$, a dark purple solid formed that was collected on a cold filter, yielding $156.8 \mathrm{mg}$ of $\mathbf{1}(70 \%)$.

Elemental analysis (Anal.) was performed under argon. Anal. Calcd for $\left[\mathrm{K}_{3}\left\{\left[\mathrm{U}(\mathrm{OR})_{3}\right]_{2}(\mu-\mathrm{N})\right\}\right] .0 .2$ (n-hexane) $\left(\mathrm{C}_{73.2} \mathrm{H}_{2.8} \mathrm{~K}_{3} \mathrm{NO}_{24} \mathrm{Si}_{6} \mathrm{U}_{2}\right)$ : C, 39.87; H, 7.53; $\mathrm{N}, 0.64$. Found: $\mathrm{C}, 39.92 ; \mathrm{H}, 7.77 ; \mathrm{N}, 0.52$.

${ }^{1} \mathrm{H}$ NMR of 1 (400 MHz, THF-d $\left.\mathrm{d}_{8}, 298 \mathrm{~K}\right): \delta$ (p.p.m.) $=1.56\left(\mathrm{~s}, 162 \mathrm{H}, \mathrm{CH}_{3}\right.$ terminal siloxide), $\left(400 \mathrm{MHz}\right.$, toluene- $\left.\mathrm{d}_{8}, 298 \mathrm{~K}\right): \delta$ (p.p.m. $)=1.74\left(\mathrm{~s}, 162 \mathrm{H}, \mathrm{CH}_{3}\right.$ terminal siloxide). ${ }^{13} \mathrm{C}$ NMR $(100.6 \mathrm{MHz}$, toluene-d $8,298 \mathrm{~K}): \delta$ (p.p.m. $)=32.2$ $\left(\mathrm{CH}_{3}\right), 74.7\left(\mathrm{CMe}_{3}\right)$.

Synthesis of $\left[\mathrm{K}_{3}\left\{\left[\mathrm{U}(\mathrm{OR})_{3}\right]_{2}(\mu-\mathrm{N})\left(\mu-\eta^{2}: \eta^{2}-\mathrm{N}_{2}\right)\right\}\right]$, compound 2 (Extended Data Fig. $7 \mathrm{~b}$ and c). Complex $\mathbf{1}(128.5 \mathrm{mg}, 0.03 \mathrm{mmol})$ was introduced into a glass tube equipped with a J. Young valve under argon in a glove box. The tube was then connected to a Schlenk line and evacuated while keeping the tube immersed in liquid nitrogen. The solid was exposed to $\mathrm{N}_{2}(0.5 \mathrm{~atm})$ for $2 \mathrm{~h}$ at room temperature. The colour of the solid changed within a few minutes from dark purple to brown. The solid was stirred every $10 \mathrm{~min}$. After $2 \mathrm{~h}$, the solid was transferred into the glove box and dissolved in toluene at $40^{\circ} \mathrm{C}$. The resulting toluene solution was filtered and left standing at $-40^{\circ} \mathrm{C}$. After 2 days, 2 precipitated out of the solution as a microcrystalline brown solid that was dried under vacuum ( $60 \mathrm{mg}, 68 \%$ yield). The labelled analogue of complex $2,\left[\mathrm{~K}_{3}\left\{\left[\mathrm{U}(\mathrm{OR})_{3}\right]_{2}(\mu-\mathrm{N})\left(\mu-\eta^{2}: \eta^{2}-{ }^{15} \mathrm{~N}_{2}\right)\right\}\right],{ }^{15} \mathrm{~N}-2$, is easily prepared using the same procedure by exposing 1 to ${ }^{15} \mathrm{~N}_{2} \cdot{ }^{1} \mathrm{H}$ NMR $(400 \mathrm{MHz}$, toluene- $\left.\mathrm{d}_{8}, 298 \mathrm{~K}\right): \delta$ (p.p.m.) $=1.34\left(\mathrm{~s}, 162 \mathrm{H}, \mathrm{CH}_{3}\right.$ terminal siloxide). ${ }^{13} \mathrm{C} \mathrm{NMR}$ $\left(100.6 \mathrm{MHz}\right.$, toluene-d $\left.\mathrm{d}_{8}, 298 \mathrm{~K}\right): \delta$ (p.p.m. $)=31.4\left(\mathrm{CH}_{3}\right), 71.6\left(\mathrm{CMe}_{3}\right)$. Anal. Calcd for $\left[\mathrm{K}_{3}\left\{\left[\mathrm{U}(\mathrm{OR})_{3}\right]_{2}(\mu-\mathrm{N})\left(\mu-\eta^{2}: \eta^{2}-\mathrm{N}_{2}\right)\right\}\right]\left(\mathrm{C}_{72} \mathrm{H}_{162} \mathrm{~K}_{3} \mathrm{~N}_{3} \mathrm{O}_{24} \mathrm{Si}_{6} \mathrm{U}_{2}\right)$ : C, 39.03; H, 7.37; $\mathrm{N}, 1.90$. Found: C, 39.05; H, 7.36; N, 1.63. $\mu_{\mathrm{eff}}(298 \mathrm{~K}): 1.80 \mu_{\mathrm{B}}$. Raman of powder, $\nu$ (intensity) $\left(\mathrm{cm}^{-1}\right): 2: 797(817) ;{ }^{15} \mathrm{~N}-2: 785(1,100)$.

No loss of $\mathrm{N}_{2}$ from 2 is observed under dynamic vacuum in the solid state or after three cycles of freeze-pump-thaw degassing under argon of a toluene or THF solution of 2 .

The synthesis can also be performed by exposure of a solution of $\mathbf{1}$ in THF or toluene solution to $\mathrm{N}_{2}$ at room temperature, but the yield for these reactions is lower due to the low solution stability of $\mathbf{1}$ at room temperature. When the previously reported caesium analogue $\left[\mathrm{Cs}_{3}\left\{\left[\mathrm{U}(\mathrm{OR})_{3}\right]_{2}(\mu-\mathrm{N})\right\}\right]$ is treated with $\mathrm{N}_{2}$, the reaction proceeds with a similar colour change. The ${ }^{1} \mathrm{H}$ NMR spectrum in THF- $\mathrm{d}_{8}$ of the crude mixture shows the presence of a new peak at -0.2 p.p.m., the presence of the previously reported $\mathrm{U}(\mathrm{III}) / \mathrm{U}(\mathrm{IV})$ and $\mathrm{U}(\mathrm{IV}) / \mathrm{U}(\mathrm{IV})$ nitride complexes $^{24}$ and free ligand.

The $\mathrm{U}(\mathrm{III}) / \mathrm{U}(\mathrm{IV}), \mathrm{U}(\mathrm{IV}) / \mathrm{U}(\mathrm{Iv})$ nitride complexes, $\left[\mathrm{M}_{2}\left\{\left[\mathrm{U}(\mathrm{OR})_{3}\right]_{2}(\mu-\mathrm{N})\right\}\right]$ and $\left[\mathrm{M}\left\{\left[\mathrm{U}(\mathrm{OR})_{3}\right]_{2}(\mu-\mathrm{N})\right\}\right],(\mathrm{M}=\mathrm{K}, \mathrm{Cs})$ do not react with $\mathrm{N}_{2}$.

Synthesis of $\left[\mathrm{K}_{2}\left\{\left[\mathrm{U}(\mathrm{OR})_{3}\right]_{2}(\mu-\mathrm{NH})\left(\mu-\eta^{2}: \eta^{2}-\mathrm{N}_{2}\right)\right\}\right]$, compound 3. A solution of 2,4,6-tri-tert-butylphenol $(2.4 \mathrm{mg}, 0.009 \mathrm{mmol}, 1 \mathrm{eq}$. $)$ in THF was added to a brown solution of $2(20 \mathrm{mg}, 0.009 \mathrm{mmol}, 1$ equiv.) in THF $(0.5 \mathrm{ml})$. The mixture was stirred for $1 \mathrm{~h}$. The colour changed from dark brown to light brown. The THF was removed under vacuum and then the residue was dissolved in toluene. The resulting solution was filtered and stored at $-40^{\circ} \mathrm{C}$. After $24 \mathrm{~h}$, brown crystals of 3 formed that were suitable for X-ray diffraction (XRD; $14.7 \mathrm{mg}, 70 \%$ yield). The ${ }^{15} \mathrm{~N}$-labelled complex, ${ }^{15} \mathrm{~N}-3$, was prepared from ${ }^{15} \mathrm{~N}-2$ following the same procedure. ${ }^{1} \mathrm{H}$ NMR spectra show that the addition of excess 2,4,6-tri-tertbutylphenol does not lead to the formation of additional protonation products. Crystals of $\mathbf{3}$ were also isolated from the reaction of complex $\mathbf{2}$ with 2 equiv. of $\mathrm{PyHCl}$ in THF, in $24 \mathrm{~h}$ from a toluene solution at $-40^{\circ} \mathrm{C} .{ }^{1} \mathrm{H}$ NMR studies show that addition of 1 equiv. of $\mathrm{PyHCl}$ affords complex 3 , unreacted starting material and other protonation products. From the reaction with 2 equiv. of $\mathrm{PyHCl}$, we have also isolated pale brown crystals of a minor product that cannot be isolated in sufficient amount for further analysis. X-ray crystallography studies indicate the presence of the doubly protonated complex, $\left[\mathrm{K}_{2}\left\{\left[\mathrm{U}(\mathrm{OR})_{3}\right]_{2}(\mu-\mathrm{NH})_{2}(\mu-\mathrm{Cl})\right], 4\right.$.

${ }^{1} \mathrm{H}$ NMR of crystals of 3 (400 MHz, THF-d $\left.{ }_{8}, 298 \mathrm{~K}\right)$ (Extended Data Fig. 7d): $\delta$ (p.p.m. $)=-1.26\left(\mathrm{~s}, 162 \mathrm{H}, \mathrm{CH}_{3}\right.$ terminal siloxide), $78(\mathrm{~s}, 1 \mathrm{H}, \mathrm{NH}) .{ }^{1} \mathrm{H}$ NMR of crystals of $3\left(400 \mathrm{MHz}\right.$, toluene- $\left.\mathrm{d}_{8}, 298 \mathrm{~K}\right): \delta$ (p.p.m. $)=-1.10\left(\mathrm{~s}, 162 \mathrm{H}, \mathrm{CH}_{3}\right.$ terminal siloxide), $78(\mathrm{~s}, 1 \mathrm{H}, \mathrm{NH}) \cdot{ }^{13} \mathrm{C}$ NMR $\left(100.6 \mathrm{MHz}\right.$, toluene- $\left.\mathrm{d}_{8}, 298 \mathrm{~K}\right): \delta$ (p.p.m. $)=29.5\left(\mathrm{CH}_{3}\right), 71.9\left(\mathrm{CMe}_{3}\right)$. Anal. Calcd for $\left[\mathrm{K}_{2}\left\{\left[\mathrm{U}(\mathrm{OR})_{3}\right]_{2}(\mu-\mathrm{NH})\left(\mu-\eta^{2}\right.\right.\right.$ : $\left.\left.\left.\eta^{2}-\mathrm{N}_{2}\right)\right\}\right]\left(\mathrm{C}_{72} \mathrm{H}_{163} \mathrm{~K}_{2} \mathrm{~N}_{3} \mathrm{O}_{24} \mathrm{Si}_{6} \mathrm{U}_{2}\right) \cdot 1.5\left(\mathrm{C}_{7} \mathrm{H}_{8}\right)$ : C, 42.78; H, 7.62; N, 1.81. Found: $\mathrm{C}$, $42.95 ; \mathrm{H}, 7.73 ; \mathrm{N}, 1.54 .{ }^{1} \mathrm{H}$ NMR of crystals of $4\left(400 \mathrm{MHz}, \mathrm{THF}-\mathrm{d}_{8}, 298 \mathrm{~K}\right): \delta$ (p.p.m.) $=0.1\left(\mathrm{~s}, 162 \mathrm{H}, \mathrm{CH}_{3}\right.$ terminal siloxide).

Ammonia formation after addition of excess $\mathrm{PyHCl}$ to compound 2 . To a brown solution of $2(20 \mathrm{mg}, 0.009 \mathrm{mmol}, 1$ equiv. $)$ in THF $(1 \mathrm{ml})$, an excess of $\mathrm{PyHCl}$ was added ( $20 \mathrm{mg}, 0.17 \mathrm{mmol}, 20$ equiv.). The mixture was stirred overnight, affording a colourless solution and a white precipitate. The supernatant was removed and the solid was washed twice with $0.5 \mathrm{ml}$ of THF. The solid was dried under vacuum and then dissolved in DMSO- $\mathrm{d}_{6} .{ }^{1} \mathrm{H}$ NMR analysis showed ammonium chloride as the only product. The reaction was repeated with the labelled ${ }^{15} \mathrm{~N}$ compound, $\left[\mathrm{K}_{3}\left\{\left[\mathrm{U}(\mathrm{OR})_{3}\right]_{2}(\mu-\mathrm{N})\left(\mu-\eta^{2}: \eta^{2}-{ }^{15} \mathrm{~N}_{2}\right)\right\}\right]$. The ratio of ${ }^{15} \mathrm{NH}_{4} \mathrm{Cl}^{14} \mathrm{NH}_{4} \mathrm{Cl}$ was found to be 1:0.85. The global yield in $\mathrm{NH}_{3}$ was determined in a separate experiment by integration (with an internal standard) of the NMR signals to be $35 \% .{ }^{1} \mathrm{H}$ NMR of $\mathrm{NH}_{4} \mathrm{Cl}\left(400 \mathrm{MHz}, \mathrm{DMSO}-\mathrm{d}_{6}, 298 \mathrm{~K}\right): \delta$ (p.p.m.) $=7.3$ (triplet, $J=52 \mathrm{~Hz}$ ); ${ }^{1} \mathrm{H}$ NMR of ${ }^{15} \mathrm{NH}_{4} \mathrm{Cl}(400 \mathrm{MHz}$, DMSO-d 6 , $298 \mathrm{~K}$ ): $\delta$ (p.p.m.) $=7.4$ (doublet, $J=72 \mathrm{~Hz}$ ) Ammonia formation after addition of an excess of ethereal $\mathrm{HCl}$ to compound 2 . To a brown solution of complex 2 (5.2 $\mathrm{mg}, 0.0023 \mathrm{mmol}, 1$ equiv.) in THF ( $1 \mathrm{ml})$, an excess of a $2 \mathrm{M}$ solution of $\mathrm{HCl}$ in $\mathrm{Et}_{2} \mathrm{O}(34.5 \mu \mathrm{l}, 0.069 \mathrm{mmol}, 30$ equiv.) was added. The reaction mixture immediately turned colourless. After $24 \mathrm{~h}$, the solvent was removed under vacuum, DMSO- $\mathrm{d}_{6}$ was added and the amount of ammonia was evaluated by quantitative ${ }^{1} \mathrm{H}$ NMR (dimethyl sulfone as internal standard) (42\% yield of ammonia).

Ammonia formation after addition of excess $\mathrm{HBAr}_{4}^{\mathrm{F}} .2 \mathrm{Et}_{2} \mathrm{O}$ to compound 2 . A Schlenk flask was charged with a solution of complex $\left[\mathrm{K}_{3}\left\{\left[\mathrm{U}(\mathrm{OR})_{3}\right]_{2}(\mu-\mathrm{N})\left(\mu-\eta^{2}\right.\right.\right.$ $\left.\left.\left.\eta^{2}-\mathrm{N}_{2}\right)\right\}\right]$ ( $10 \mathrm{mg}, 0.0045 \mathrm{mmol}, 1$ equiv.) in $2 \mathrm{ml}$ of $\mathrm{Et}_{2} \mathrm{O}$ and it was cooled down to $-70^{\circ} \mathrm{C}$. $\mathrm{HBAr}_{4} \cdot 2 \mathrm{Et}_{2} \mathrm{O}$ (114 mg, $0.11 \mathrm{mmol}, 25$ equiv.) was dissolved in $\mathrm{Et}_{2} \mathrm{O}$ and 
cooled down to $-70^{\circ} \mathrm{C}$. The $\mathrm{HBAr}_{4}^{\mathrm{F}} \cdot 2 \mathrm{Et}_{2} \mathrm{O}$ solution was added and the mixture was stirred for $10 \mathrm{~min}$ at $-70^{\circ} \mathrm{C}$. The reaction mixture was stirred at room temperature for $15 \mathrm{~min}$. All the volatiles were then vacuum transferred into a Schlenk flask containing a $2 \mathrm{M} \mathrm{HCl}$ solution in $\mathrm{Et}_{2} \mathrm{O}(4 \mathrm{ml}) . \mathrm{NaO}^{t} \mathrm{Bu}(40 \mathrm{mg}$ in $3 \mathrm{ml}$ of $\mathrm{Et}_{2} \mathrm{O}$ ) was added to the residual solid. It was stirred for $10 \mathrm{~min}$ at room temperature and then the volatiles were vacuum transferred into the Schlenk flask containing the ethereal $\mathrm{HCl}$ solution $\left(\mathrm{HCl}\left(\mathrm{Et}_{2} \mathrm{O}\right)\right)$. The $\mathrm{HCl}\left(\mathrm{Et}_{2} \mathrm{O}\right)$ was removed under vacuum and the resulting white solid was dissolved in DMSO- $\mathrm{d}_{6}$ to evaluate the amount of ammonia (present as its conjugate acid, $\mathrm{NH}_{4}^{+}$) formed ( $25 \%$ yield) by quantitative ${ }^{1} \mathrm{H}$ NMR spectroscopy (dimethyl sulfone as internal standard). The same result was obtained in a separate experiment by dissolving the white solid in $20 \mathrm{ml}$ of distilled water for the indophenol test for ammonia quantification (25\% yield of ammonia).

Ammonia formation after reaction of compound 2 with $\mathrm{H}_{2}$ and $\mathrm{HCl}\left(\mathrm{Et}_{2} \mathrm{O}\right)$. In an NMR tube, a brown solution of $2(5.2 \mathrm{mg}, 0.0023 \mathrm{mmol})$ in $0.5 \mathrm{ml}$ of toluene was prepared in a glovebox under argon. The solution was freeze-degassed three times and exposed to $1 \mathrm{~atm}$ of hydrogen gas. The tube was closed and left for three weeks at room temperature, until the starting material had disappeared. The ${ }^{1} \mathrm{H}$ NMR spectrum shows only the presence of free ligand in $10 \%$ yield (Extended Data Fig. 4a). After three weeks, all the volatiles were vacuum transferred into a Schlenk flask containing a $2 \mathrm{M} \mathrm{HCl}$ solution in $\mathrm{Et}_{2} \mathrm{O}(4 \mathrm{ml})$. After removal of the $\mathrm{HCl}\left(\mathrm{Et}_{2} \mathrm{O}\right)$ solution under vacuum, no white precipitate was visible. The absence of ammonium chloride was confirmed by ${ }^{1} \mathrm{H}$ NMR spectroscopy. To the residual solid left in the NMR tube, $1 \mathrm{ml}$ of a solution of $2 \mathrm{M} \mathrm{HCl}$ in $\mathrm{Et}_{2} \mathrm{O}$ was added. Immediately, white solid precipitated out of the solution. $\mathrm{HCl}\left(\mathrm{Et}_{2} \mathrm{O}\right)$ was removed under vacuum and the white solid was titrated in DMSO- $\mathrm{d}_{6}$ using dimethyl sulfone as an internal standard (77\% yield in ammonia).

Preliminary studies show that hydrogenation of complex $\mathbf{3}$ does not lead to decomposition, but to the clean formation of a new uranium species (Extended Data Fig. 8a). Preliminary X-ray diffraction data measured for the new species show the presence of three non-bonded nitrogen atoms bridging two uranium centres, in agreement with the cleavage of the hydrazido bond by hydrogen.

Reaction of compound 2 with $\mathrm{CO}$, synthesis of $\left[\mathrm{K}_{2}\left\{\left[\mathrm{U}(\mathrm{OR})_{3}\right]_{2}(\mu-\mathrm{O})(\mu-\mathrm{NCO})_{2}\right\}\right]$, compound 5. A brown solution of $2\left(19 \mathrm{mg}, 0.0086 \mathrm{mmol}, 1\right.$ equiv.) in benzene- $\mathrm{d}_{6}$ $(0.5 \mathrm{ml})$ was prepared in a glovebox under argon, and then freeze-degassed three times. 10 equivalents of $\mathrm{CO}$ were then added at room temperature. The solution turned light yellow. The ${ }^{1} \mathrm{H}$ NMR spectrum of the reaction mixture shows the presence of only one signal. The benzene was removed and THF $(0.1 \mathrm{ml})$ was added. Then the suspension was filtered and the resulting solution was left standing at $-40{ }^{\circ} \mathrm{C}$. After $48 \mathrm{~h}$, X-ray suitable brown crystals of 5 formed $(13 \mathrm{mg}, 68 \%$ yield). The ${ }^{15} \mathrm{~N}$-labelled complex ${ }^{15} \mathrm{~N}-5$ was prepared from ${ }^{15} \mathrm{~N}-2$ following the same procedure.

IR, $\nu \mathbf{N}^{13} \mathbf{C O}\left(\mathrm{cm}^{-1}\right): 2,195 .{ }^{13} \mathrm{C}$ NMR of the evaporated reaction mixture $\left(400 \mathrm{MHz}, \mathrm{D}_{2} \mathrm{O}, 298 \mathrm{~K}\right): \delta$ (p.p.m.) $=129(\mathrm{NCO}), 164(\mathrm{CN}) .{ }^{1} \mathrm{H}$ NMR of crystals of complex 5 ( $\left.400 \mathrm{MHz}, \mathrm{C}_{6} \mathrm{D}_{6}, 298 \mathrm{~K}\right): \delta$ (p.p.m.) $=1.07$ (s, $162 \mathrm{H}, \mathrm{CH}_{3}$ terminal siloxide). ${ }^{13} \mathrm{C}$ NMR of reaction mixture $\left(100.6 \mathrm{MHz}, \mathrm{C}_{6} \mathrm{D}_{6}, 298 \mathrm{~K}\right): \delta$ (p.p.m. $)=-164$ (NCO), $30.8\left(\mathrm{CH}_{3}\right), 73.3\left(\mathrm{CMe}_{3}\right)$. Anal. Calcd for $\left[\mathrm{K}_{2}\left\{\left[\mathrm{U}(\mathrm{OR})_{3}\right]_{2}(\mu-\mathrm{O})(\mu-\mathrm{NCO})_{2}\right\}\right]$ $\left(\mathrm{C}_{74} \mathrm{H}_{162} \mathrm{~K}_{2} \mathrm{~N}_{2} \mathrm{O}_{27} \mathrm{Si}_{6} \mathrm{U}_{2}\right): \mathrm{C}, 39.77 ; \mathrm{H}, 7.31 ; \mathrm{N}, 1.25$. Found: C, 39.74; H, 7.21; $\mathrm{N}, 1.27$.

${ }^{13} \mathrm{C}$ NMR of ${ }^{15} \mathrm{~N}-5$ in $\mathrm{C}_{6} \mathrm{D}_{6}$ shows the presence of a broad peak at -164 p.p.m. $\left(\mathrm{NCO}^{-}\right)$. The ${ }^{13} \mathrm{C}$ NMR in $\mathrm{D}_{2} \mathrm{O}$ of the solid recovered after evaporation of the solvent from the reaction mixture shows a doublet at 129 p.p.m. $\left(J=64,{ }^{15} \mathrm{~N}^{13} \mathrm{CO}\right)$ and a singlet at 165 p.p.m. $\left({ }^{13} \mathrm{C}^{14} \mathrm{~N}\right)$, in a ratio of 2:1, respectively.

Reaction of compound 3 with $\mathrm{CO}$, synthesis of $\left[\mathrm{K}_{2}\left\{\left[\mathrm{U}(\mathrm{OR})_{3}\right]_{2}(\mu-\mathrm{NH})\right.\right.$ ( $\mu$-NCO)\}], compound 6. A brown solution of $3(11.5 \mathrm{mg}, 0.0053 \mathrm{mmol}, 1$ equiv.) in toluene $(0.5 \mathrm{ml})$ was prepared under argon in a tube equipped with a J. Young valve. It was freeze-degassed three times and then 10 equiv. of $\mathrm{CO}$ were added. The solution turned yellow and ${ }^{1} \mathrm{H}$ NMR spectroscopy indicated completion of the reaction within $24 \mathrm{~h}$. X-ray suitable orange crystals of $\mathbf{6}$ were isolated from toluene after storing solution at room temperature for $24 \mathrm{~h}$ ( $8 \mathrm{mg}, 70 \%$ yield). The ${ }^{15} \mathrm{~N}$-labelled complex ${ }^{15} \mathrm{~N}-6$ was prepared from ${ }^{15} \mathrm{~N}-3$ following the same procedure. Titration of the residual compound present in the mother liquor shows the presence of an additional amount of 6 to afford an overall yield of $80 \%$. The ${ }^{1} \mathrm{H}$ NMR spectrum showed that when 100 equiv. of $\mathrm{CO}$ are added to 3 , a different species identified as a bis(cyanate) complex, $\left[\mathrm{K}_{2}\left\{\left[\mathrm{U}(\mathrm{OR})_{3}\right]_{2}(\mu-\mathrm{NH})(\mu-\mathrm{NCO})_{2}\right\}\right]$, is formed (Extended Data Fig. 8b). In contrast, complex 6 does not react with carbon monoxide or with 2,4,6-tri-tert-butylphenol.

${ }^{13} \mathrm{C}$ NMR spectroscopy in $\mathrm{D}_{2} \mathrm{O}$ of the residue obtained after removal of the solvent from the reaction of 3 with $\mathrm{CO}$ (10 equiv.) only shows the presence of the signal at 130.0 p.p.m. assigned to cyanate; no formation of cyanide is observed.

The addition of excess $\mathrm{PyHCl}$ (20 equiv.) to complex ${ }^{15} \mathrm{~N}-6$ leads to the formation of a precipitate. The ${ }^{1} \mathrm{H}$ NMR spectrum in DMSO- $\mathrm{d}_{6}$ of this solid shows the presence of signals assigned to ${ }^{15} \mathrm{NH}_{4} \mathrm{Cl}$ (doublet) and ${ }^{14} \mathrm{NH}_{4} \mathrm{Cl}$ (triplet), suggesting that hydrazide/nitride exchange occurs during protonation of $\mathbf{2}$ to yield 3 (Extended Data Fig. 8c).

IR, $\nu \mathrm{N}^{13} \mathrm{CO}\left(\mathrm{cm}^{-1}\right): 2,135, \nu \mathrm{NH}\left(\mathrm{cm}^{-1}\right): 3,428 .{ }^{1} \mathrm{H}$ NMR of crystals of $6\left(400 \mathrm{MHz}\right.$, toluene- $\left.\mathrm{d}_{8}, 298 \mathrm{~K}\right): \delta$ (p.p.m. $)=0.36\left(\mathrm{~s}, 162 \mathrm{H}, \mathrm{CH}_{3}\right.$ terminal siloxide). ${ }^{13} \mathrm{C}$ NMR of crystals of 6 ( $100.6 \mathrm{MHz}$, toluene-d $\left.\mathrm{d}_{8}, 298 \mathrm{~K}\right): \delta$ (p.p.m.) $=145$ (NCO). Anal. Calcd for $\left[\mathrm{K}_{2}\left\{\left[\mathrm{U}(\mathrm{OR})_{3}\right]_{2}(\mu-\mathrm{NH})(\mu-\mathrm{NCO})\right\}\right]\left(\mathrm{C}_{73} \mathrm{H}_{163} \mathrm{~K}_{2} \mathrm{~N}_{2} \mathrm{O}_{25} \mathrm{Si}_{6} \mathrm{U}_{2}\right)$ : C, $40.02 ; \mathrm{H}, 7.45 ; \mathrm{N}, 1.28$. Found: C, 40.25; H, 7.22; N, 1.67 .

Preliminary attempts at reducing complex 6 were performed at $-70^{\circ} \mathrm{C}$ in THF$\mathrm{d}_{8}$ by addition of 10 equiv. of $\mathrm{KC}_{8}$. The ${ }^{1} \mathrm{H}$ NMR spectrum $\left(400 \mathrm{MHz}\right.$, toluene- $\mathrm{d}_{8}$ $233 \mathrm{~K}$ ) shows the presence of free ligand and of a new species at -1.3 p.p.m. in a ratio of 1:0.5, respectively. Attempts to isolate the new species were not successful. Single-crystal X-ray crystallographic analyses. The crystallographic data of 1,2 and 3.toluene are presented in Extended Data Table 1 and those of 4, 5.THF and $\mathbf{6}$ in Extended Data Table 2. The diffraction data of $\mathbf{1}$ were measured at low temperature (100(2) K) using Mo Ko radiation on a Bruker APEX II CCD diffractometer equipped with a kappa geometry goniometer. The data set was reduced by EvalCCD ${ }^{31}$ and then corrected for absorption ${ }^{32}$. The data collection of 2 and 3.toluene ( 3 co-crystallizes with a toluene molecule), 4,5 .THF ( 5 co-crystallizes with a THF molecule) and $\mathbf{6}$ were performed at low temperature (140(2) K for $\mathbf{2}$, 3.toluene, 5.THF and 6; 100(2) K for 4) $\mathrm{Cu} \mathrm{K \alpha}$ radiation $(\lambda=1.54184 \AA$ ) for 2 , 3.toluene, 4 and 5.THF and Mo K $\alpha$ radiation $(\lambda=0.71073 \AA)$ for 6 on a Rigaku SuperNova dual system in combination with an Atlas S2 CCD detector for the compounds 3.toluene and 5.THF and one equipped with an Atlas CCD detector for the compounds $\mathbf{4}$ and $\mathbf{6}$. The data reduction was carried out by CrysAlis ${ }^{\mathrm{PRO}}$ (ref. 33). The solution and refinement of the structure was performed with SHELXS-97 ${ }^{34}$, SHELXL-2016 (release 4$)^{35}$, and SHELXL-2014 (release 7) ${ }^{34}$. The crystal structures were refined using full-matrix least-squares based on $F^{2}$ with all non-hydrogen atoms anisotropically defined. Hydrogen atoms were placed in calculated positions by means of the 'riding' model. In the case of $\mathbf{1}$, extensive disorder was encountered during the refinement of one -OSi(Ot-butyl $)_{3}$ moiety and the split model combined with reasonable restraints (SADI, SIMU instructions in the SHELXL program) was employed to correctly treat it. Some geometrical restraints (SADI card) were applied to $3 t$-butyl substituents and all carbon atoms were refined anisotropically but their thermal parameters were submitted to restraints (SIMU). The SQUEEZE ${ }^{36}$ algorithm of PLATON was employed in the last stages of refinement to take into account spurious electron density peaks, probably due to disordered solvent molecules. In the case of $2, \mathrm{~K}$ and $\mathrm{N}$ atoms displayed a disordered arrangement complicated by symmetry (three-fold axes); $\mathrm{K}$ was treated by the split model whereas in the case of nitrogen atoms the occupancies were fixed to $1 / 3$ for symmetry reasons. The displacement parameters of N1 and $\mathrm{N} 3$ were constrained by means of the EADP command. As for 1, restraints (ISOR card) were applied to the thermal parameters of all carbons. Additional electron density found in the difference Fourier map (due to highly disordered solvent) of compounds $\mathbf{3}, \mathbf{4}, \mathbf{5}$ and $\mathbf{6}$ was treated by the SQUEEZE algorithm of PLATON ${ }^{36}$. The $\mu-\mathrm{N}_{2}$ molecule and the $\mu-\mathrm{NH}$ group bridging the metal centres in 3 were split into two orientations. The major and minor parts were refined anisotropically, but distance and similarity restraints (DFIX, SIMU and ISOR) had to be applied for a convergent least-square refinement, yielding site occupancy ratios of $0.57(2) / 0.43(2)$. In 4 the $\mu-\mathrm{Cl}$ and $\mu-\mathrm{NH}$ bridging metal centres were split into two orientations. Two parts were modelled over two half-occupied sites, which were refined anisotropically, but distance and similarity restraints (SADI, SIMU and ISOR) had to be applied for a convergent least-square refinement. In 6 the $\mu_{2}$-NCO bridging metal centres was split into two orientations. The major and minor parts were refined anisotropically, but distance and similarity restraints and constrains (DFIX, SADI, ISOR and EADP) had to be applied for a convergent least-square refinement, yielding to site occupancy ratios of $0.57(1) / 0.43(1)$.

Magnetic and EPR analyses. Magnetic measurements were performed using a Quantum Design MPMS-5T superconducting quantum interference device (SQUID) magnetometer in a temperature range $2-300 \mathrm{~K}$. The powder sample was enclosed in an evacuated quartz capsule and placed inside a plastic straw. The measurements were performed with applied magnetic field of $0.1 \mathrm{~T}$ in the zero-field cooled (ZFC) regime. The solid-state magnetic moment of 2 at $298 \mathrm{~K}$ was found to be of $1.80 \mu_{\mathrm{B}}$ (where $\mu_{\mathrm{B}}$ is Bohr magneton units) per uranium. This value is significantly lower than the theoretical $\mathrm{U}^{\mathrm{v}}$ free ion value $\left(\mu_{\text {eff }}=2.54 \mu_{\mathrm{B}}\right)$ but is in the range of magnetic moments previously reported for $\mathrm{U}^{\mathrm{v}}$ complexes $\left(1.35-3.40 \mu_{\mathrm{B}}\right)^{37}$. The value of the magnetic moment per uranium decreases gradually with temperature, reaching $1.44 \mu_{\mathrm{B}}$ at $50 \mathrm{~K}$ and then more rapidly reaching a value of $0.48 \mu_{\mathrm{B}}$ at $5 \mathrm{~K}$. This temperature response of the magnetic moment is also characteristic of $\mathrm{U}^{\mathrm{v}}$ complexes. The magnetic susceptibility of $\mathbf{2}$ (Extended Data Fig. 1b) shows a paramagnetic behaviour from $300 \mathrm{~K}$ down to approximately $50 \mathrm{~K}$ where a deviation occurs, which can probably be attributed to antiferromagnetic coupling between two uranium spins. The X-band $(9.40 \mathrm{GHz})$ 


\section{LETTER RESEARCH}

EPR spectrum of 2 (Extended Data Fig. 1a) was measured on a solution of $\mathbf{2}$ ( $2 \mathrm{mg}$, $0.0009 \mathrm{mmol})$ in $170 \mu \mathrm{l}$ of a mixture of toluene/n-hexane $(1: 1)$, with a Bruker Elexsys E500 spectrometer working at $9.4 \mathrm{GHz}$ frequency with an Oxford ESR900 cryostat for 4-300 K operation. Baseline correction of the raw EPR spectrum was performed with cubic spline (Xepr 2.4b.12, Bruker). Simulations were performed with the Easyspin 5.1.3 program ${ }^{38}$. The X-band $(9.40 \mathrm{GHz})$ EPR spectrum of complex 2 shows an intense signal at $10 \mathrm{~K}$ that was fitted with a rhombic set of $g$-values $\left(g_{1}=1.73 ; g_{2}=0.78 ; g_{3}=0.46\right)$, confirming the presence of uranium in the +5 oxidation state. The $g$ values of 2 can be compared to those reported for an octahedral uranium(v) monoxo-complex $\left(g_{1}=1.248 ; g_{2}=0.856 ; g_{3}=0.485\right)^{39}$. Data availability. The data supporting the findings of this study are available within the main text and Extended Data. Atomic coordinates and structure factors for the reported crystal structures have been deposited in the Cambridge Crystallographic Data Centre under the accession codes CCDC 1517461 (1), 1517458 (2), 1517463 (3.toluene), 1517459 (4), 1517462 (5.THF) and 1517460 (6). These data can be obtained free of charge from The Cambridge Crystallographic Data Centre (www.ccdc.cam.ac.uk/data_request/cif).
31. Duisenberg, A. J. M., Kroon-Batenburg, L. M. J. \& Schreurs, A. M. M. An intensity evaluation method: EVAL-14. J. Appl. Crystallogr. 36, 220-229 (2003).

32. Blessing, R. H. An empirical correction for absorption anisotropy. Acta Crystallogr. A 51, 33-38 (1995)

33. CrysAlis PRO (Rigaku Oxford Diffraction Ltd, Yarnton, Oxfordshire, UK, 2015).

34. Sheldrick, G. M. A short history of SHELX. Acta Crystallogr. A 64, 112-122 (2008)

35. Sheldrick, G. M. Crystal structure refinement with SHELXL. Acta Crystallogr. A 71, 3-8 (2015)

36. Spek, A. L. PLATON SQUEEZE: a tool for the calculation of the disordered solvent contribution to the calculated structure factors. Acta Crystallogr. C 71 9-18 (2015).

37. Kindra, D. R. \& Evans, W. J. Magnetic susceptibility of uranium complexes. Chem. Rev. 114, 8865-8882 (2014).

38. Stoll, S. \& Schweiger, A. EasySpin, a comprehensive software package for spectral simulation and analysis in EPR. J. Magn. Reson. 178, 42-55 (2006).

39. Cooper, O. et al. Multimetallic cooperativity in uranium-mediated $\mathrm{CO}_{2}$ activation. J. Am. Chem. Soc. 136, 6716-6723 (2014). 


\section{RESEARCH LETTER}

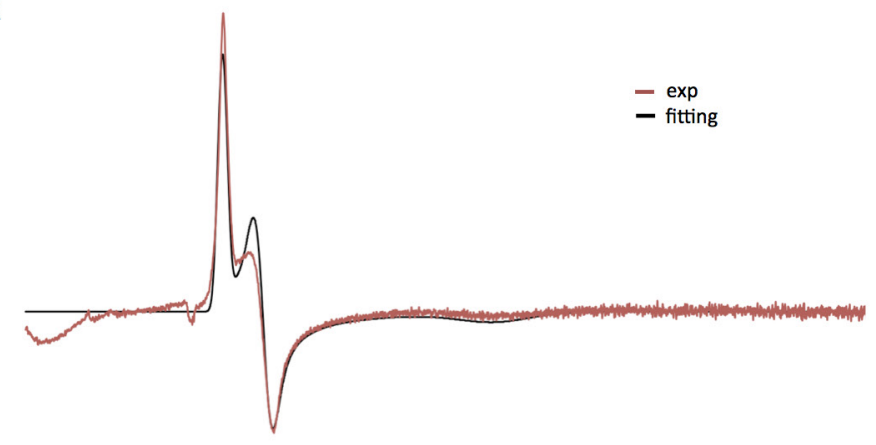

0

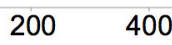

600 800

1000

1200

1400

Magnetic field (mT)

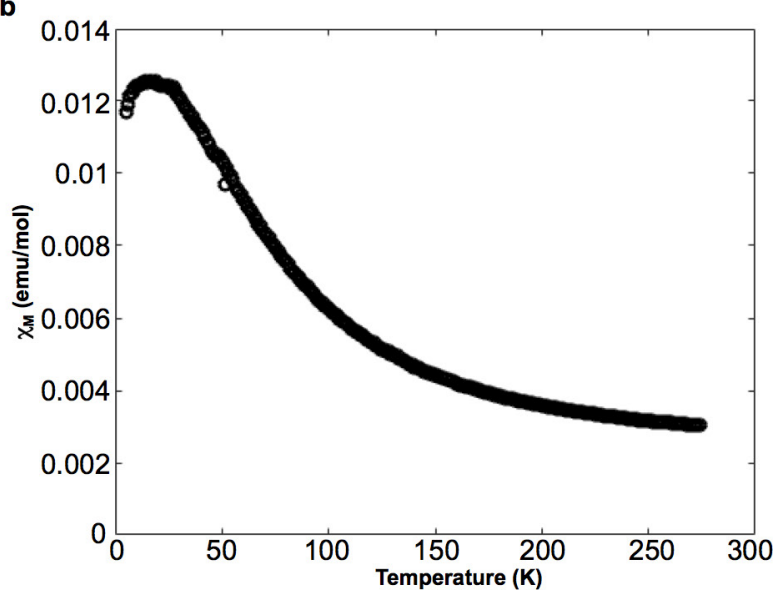

Extended Data Figure 1 | EPR and magnetic data. a, X-band $(9.40 \mathrm{GHz})$ EPR spectrum of 2 in toluene/hexane glass at $10 \mathrm{~K}$ (red line, experiment; black line, fit to two $5 f^{1}$ ions). b. Plot of measured magnetic susceptibility $\chi_{\mathrm{M}}$ for 2 versus temperature. The measurements were repeated twice. 


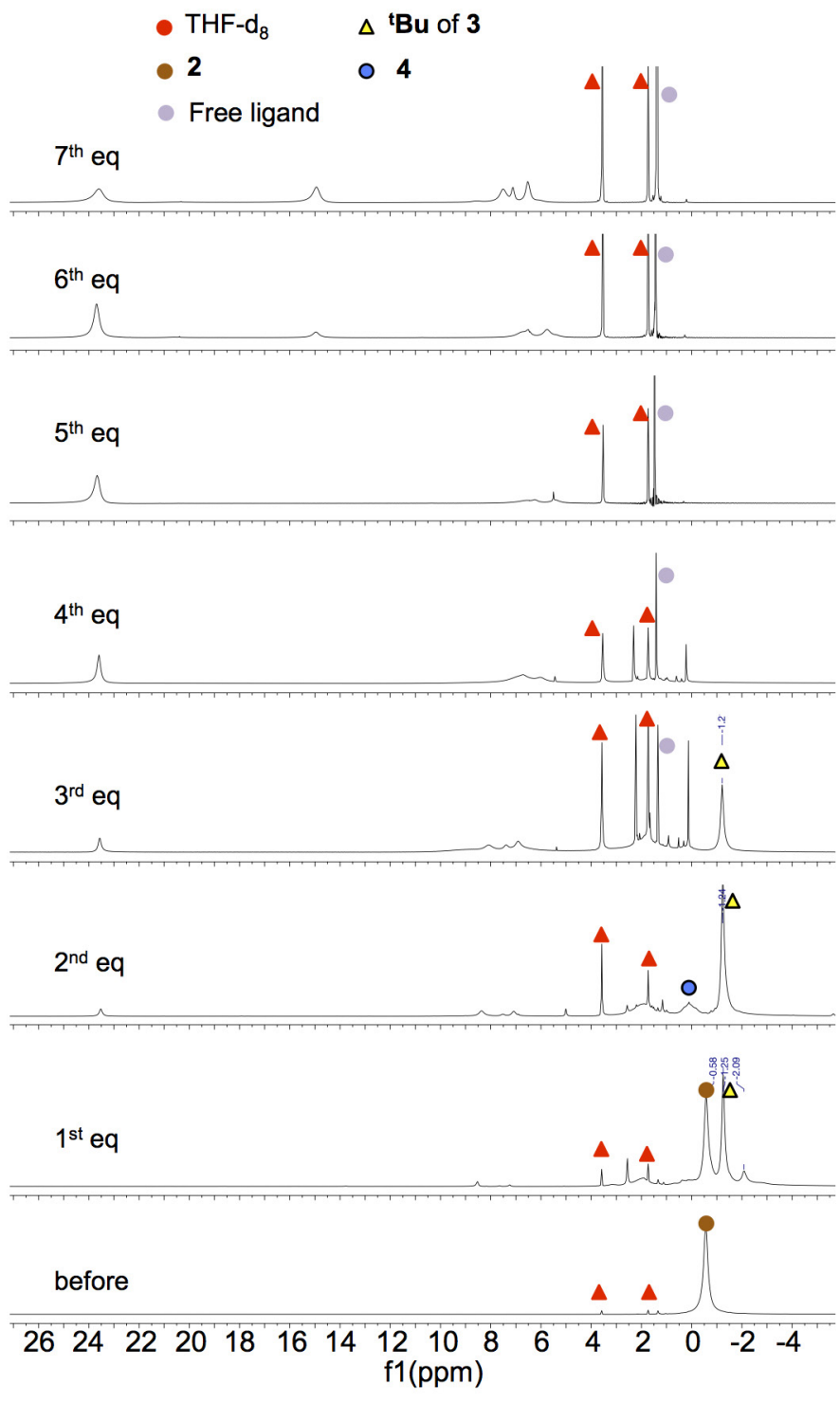

Extended Data Figure 2 | Protonation of complex $2 .{ }^{1} \mathrm{H}$ NMR spectra $\left(400 \mathrm{MHz}, \mathrm{THF}-\mathrm{d}_{8}, 298 \mathrm{~K}\right)$ for the successive addition of 1 equiv. $\mathrm{PyHCl}$ (up to 7 equiv.) to 2 . Bottom trace, before addition of $\mathrm{PyHCl}$. Symbols on peaks show assignments (see key at top); $f_{1}$, chemical shift. 


\section{RESEARCH LETTER}

a

$\mathrm{PyHCl}$ in excess

○ $\mathrm{NH}_{4} \mathrm{Cl}$

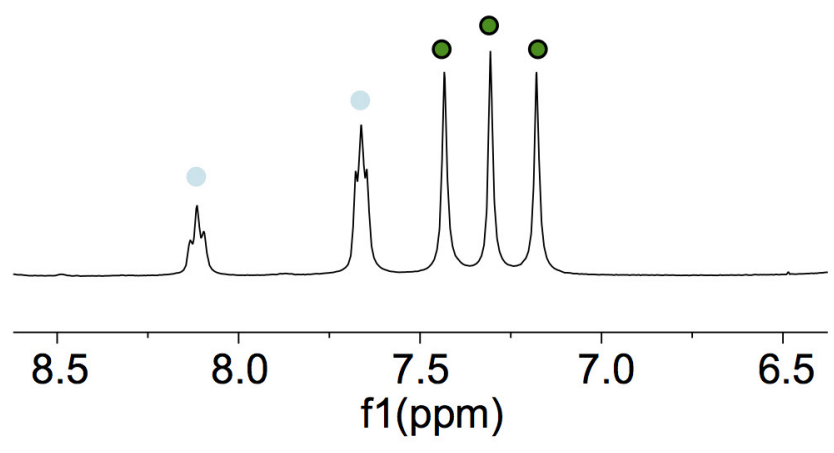

C

- DMSO-d $_{6}$

○ $\mathrm{NH}_{4} \mathrm{Cl}$

* Dimethylsulfone b

${ }^{15} \mathrm{NH}_{4} \mathrm{Cl}$

○ $\mathrm{NH}_{4} \mathrm{Cl}$

PyHCl excess
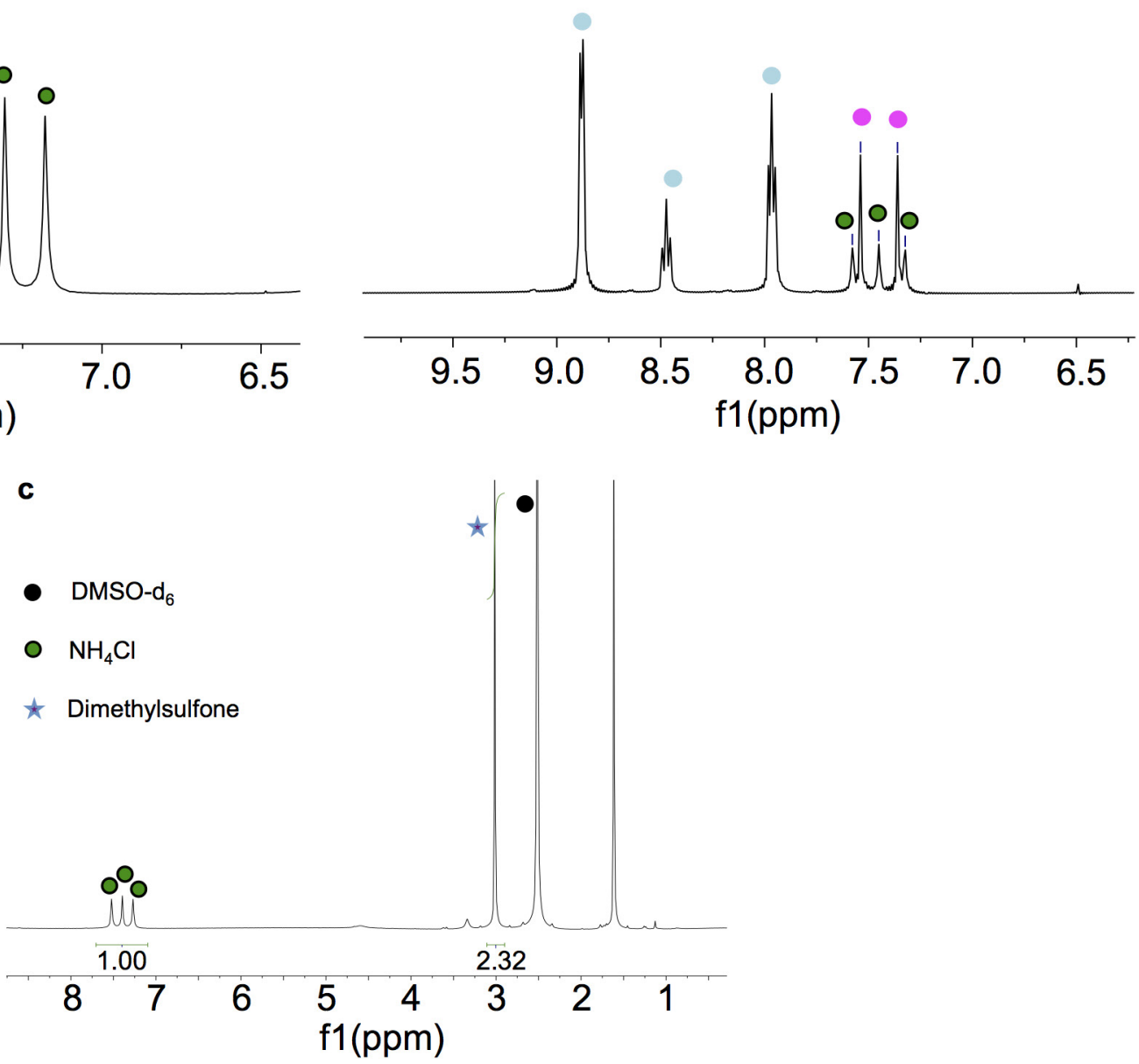

Extended Data Figure 3 Formation of ammonia from the addition of $\mathbf{H}^{+}$to 2 and to ${ }^{15} \mathrm{~N}-2$. Shown are ${ }^{1} \mathrm{H}$ NMR spectra $\left(400 \mathrm{MHz}, \mathrm{DMSO}-\mathrm{d}_{6}\right.$, PyHCl (20 equiv.) to ${ }^{15} \mathrm{~N}-2 ; \mathbf{c}, \mathrm{NH}_{4} \mathrm{Cl}$ formed after addition of $\mathrm{HCl}\left(\mathrm{Et}_{2} \mathrm{O}\right)$ to 2 (2 equiv. of dimethyl sulfone added for quantitative determination). In each panel, symbols on peaks show assignments (see key at top). 
a

- $\mathrm{C}_{7} \mathrm{D}_{8}$

- 2

- Free ligand
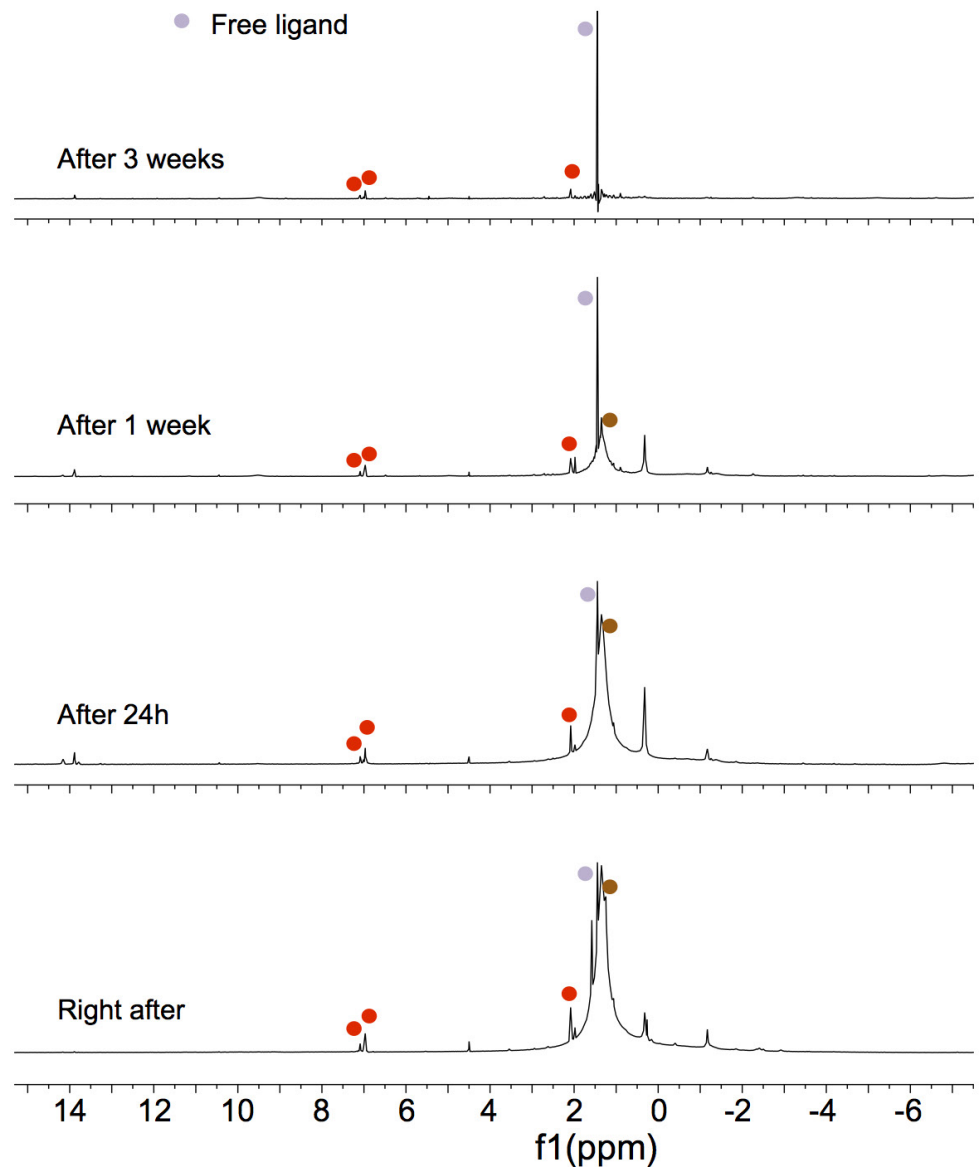

b
- DMSO-d $_{6}$
- $\mathrm{NH}_{4} \mathrm{Cl}$
$\star$ Dimethylsulfone
$+\mathrm{Et}_{2} \mathrm{O}$

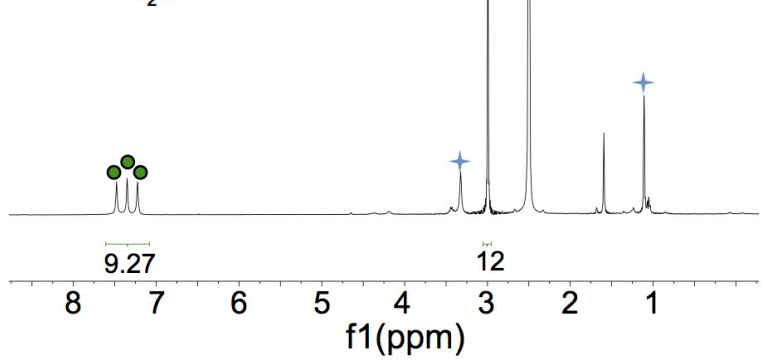

C

- DMSO-d $_{6}$

- $\mathrm{NH}_{4} \mathrm{Cl}$

- ${ }^{15} \mathrm{NH}_{4} \mathrm{Cl}$

$\star$ Dimethylsulfone

$+\mathrm{Et}_{2} \mathrm{O}$

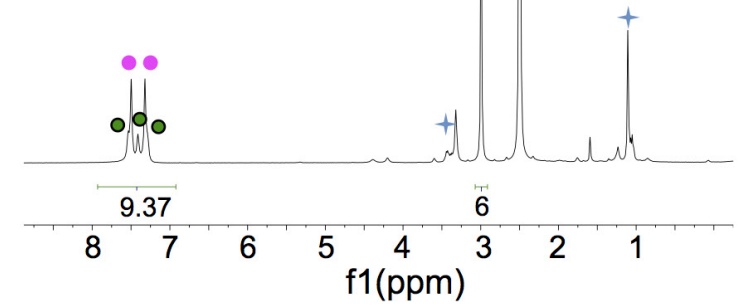

Extended Data Figure 4 Hydrogenation of 2 and formation of ammonia from the addition of $\mathrm{H}_{2} / \mathrm{H}^{+}$to 2 and to ${ }^{15} \mathrm{~N}-2$. a, ${ }^{1} \mathrm{H} \mathrm{NMR}$ spectra ( $400 \mathrm{MHz}, \mathrm{C}_{7} \mathrm{D}_{8}, 298 \mathrm{~K}$ ) of the crude reaction mixture at different times after reaction of 2 with $\mathrm{H}_{2}(1 \mathrm{~atm})$ at room temperature. Bottom trace, immediately after $\mathrm{H}_{2}$ addition. $\mathbf{b}$, $\mathbf{c}$, Quantitative ${ }^{1} \mathrm{H}$ NMR spectra ( $400 \mathrm{MHz}, \mathrm{DMSO}-\mathrm{d}_{6}, 298 \mathrm{~K}$ ) of: $\mathbf{b}, \mathrm{NH}_{4} \mathrm{Cl}$ formed after addition of
$\mathrm{HCl}\left(\mathrm{Et}_{2} \mathrm{O}\right)$ to the residual solid of reaction between 2 and $\mathrm{H}_{2}$ (2 equiv. of dimethyl sulfone added); $\mathbf{c}{ }^{15} \mathrm{NH}_{4} \mathrm{Cl}$ and $\mathrm{NH}_{4} \mathrm{Cl}$ formed in 2:1 ratio after addition of $\mathrm{HCl}\left(\mathrm{Et}_{2} \mathrm{O}\right)$ to the residual solid from the reaction between complex ${ }^{15} \mathrm{~N}-2$ and $\mathrm{H}_{2}$ (1 equiv. of dimethyl sulfone added). In each panel, symbols on peaks show assignments (see key at top). 


\section{RESEARCH LETTER}
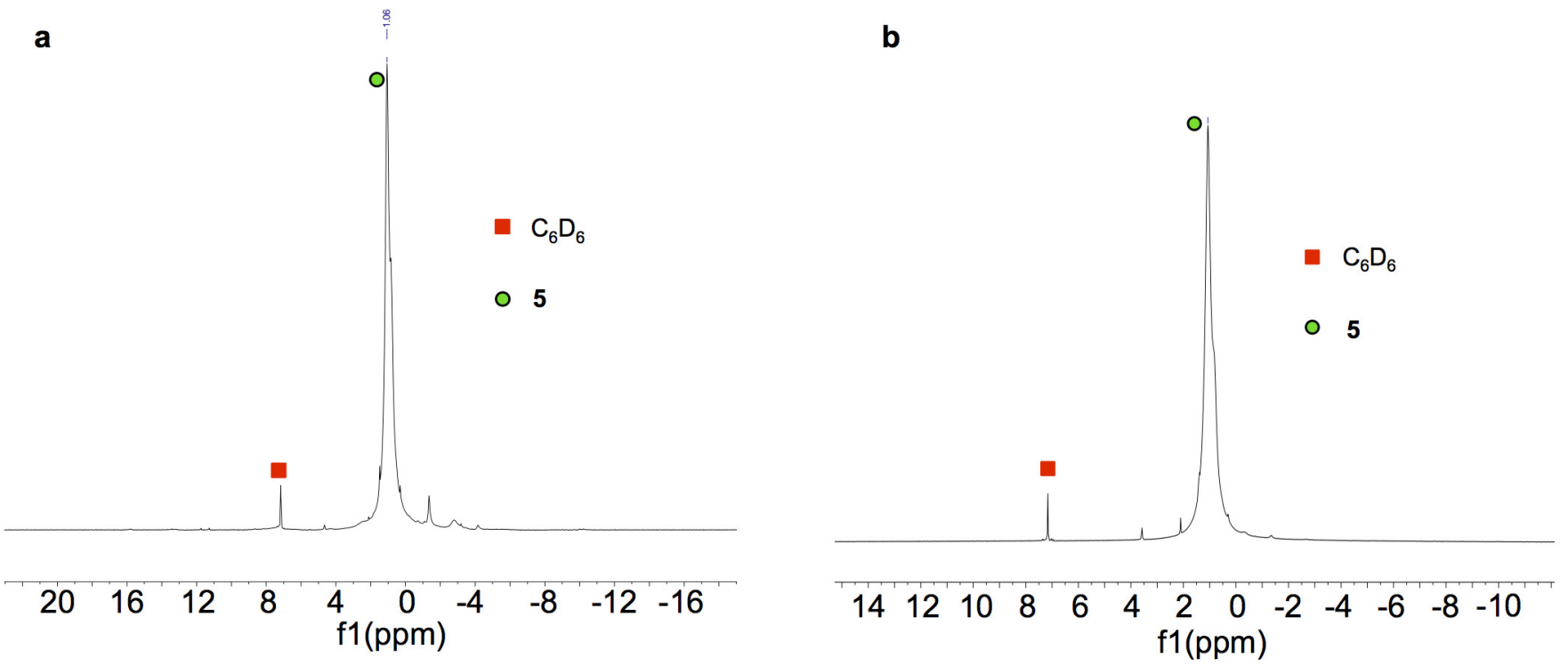

c

- ${ }^{15} \mathrm{~N}^{13} \mathrm{CO}$

$\circ{ }^{13} \mathrm{C}^{14} \mathrm{~N}$

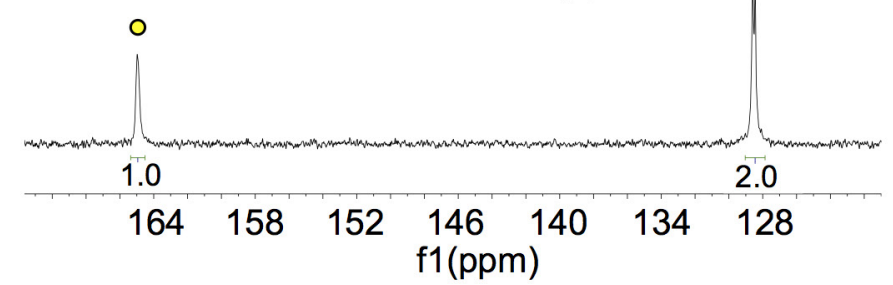

Extended Data Figure 5 Summary of ${ }^{1} \mathrm{H}$ NMR and ${ }^{13} \mathrm{C}$ NMR data for 5. a, ${ }^{1} \mathrm{H}$ NMR spectrum $\left(400 \mathrm{MHz}, \mathrm{C}_{6} \mathrm{D}_{6}, 298 \mathrm{~K}\right)$ of the crude mixture $1 \mathrm{~h}$ after addition of 10 equiv. of $\mathrm{CO}$ to 2 to afford $\mathbf{5}$. b, ${ }^{1} \mathrm{H}$ NMR spectrum $\left(400 \mathrm{MHz}, \mathrm{C}_{6} \mathrm{D}_{6}, 298 \mathrm{~K}\right)$ of crystals of 5. c, ${ }^{13} \mathrm{C}$ NMR spectrum $(100.6 \mathrm{MHz}$,
$\mathrm{D}_{2} \mathrm{O}, 298 \mathrm{~K}$ ) of the crude mixture after addition of 10 equiv. of $\mathrm{CO}$ to 2 , showing the presence of ${ }^{13} \mathrm{C}^{14} \mathrm{~N}^{-}$and $\mathrm{O}^{13} \mathrm{C}^{15} \mathrm{~N}^{-}$in a 1:2 ratio; inset shows the doublet nature of the peak assigned to $\mathrm{O}^{13} \mathrm{C}^{15} \mathrm{~N}^{-}$. In each panel, symbols on peaks show assignments (see key at top). 
a

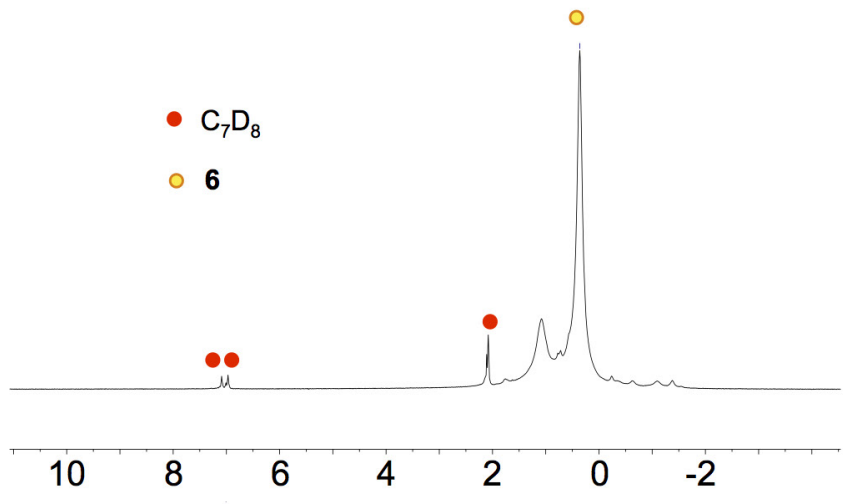

C

- DMSO

- $\mathrm{N}^{13} \mathrm{CO}$

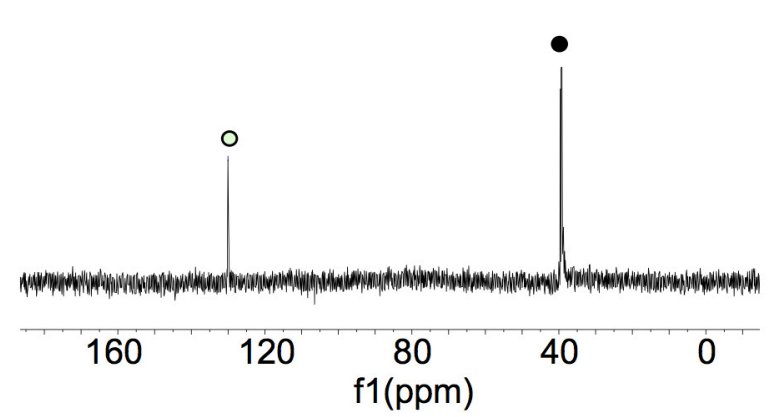

Extended Data Figure 6 | Summary of ${ }^{1} \mathrm{H}$ NMR and ${ }^{13} \mathrm{C}$ NMR data for 6. a, ${ }^{1} \mathrm{H}$ NMR spectrum $\left(400 \mathrm{MHz}, \mathrm{C}_{7} \mathrm{D}_{8}, 298 \mathrm{~K}\right)$ of crystals of $\mathbf{6} . \mathbf{b},{ }^{13} \mathrm{C} \mathrm{NMR}$ spectrum $\left(400 \mathrm{MHz}, \mathrm{C}_{7} \mathrm{D}_{8}, 298 \mathrm{~K}\right)$ of crystals of $\mathbf{6} . \mathbf{c},{ }^{13} \mathrm{C}$ NMR spectrum (400 MHz, $\mathrm{D}_{2} \mathrm{O}$ (DMSO as reference), $298 \mathrm{~K}$ ) of the crude reaction mixture after addition of 10 equiv. of $\mathrm{CO}$ to complex 3. d, Mass spectrum of the gas evolved during the reaction of ${ }^{15} \mathrm{~N}-3$ with $\mathrm{CO}$, showing formation of b

- $\mathrm{C}_{7} \mathrm{D}_{8}$

o Bound $\mathrm{N}^{13} \mathrm{CO}$ in 6

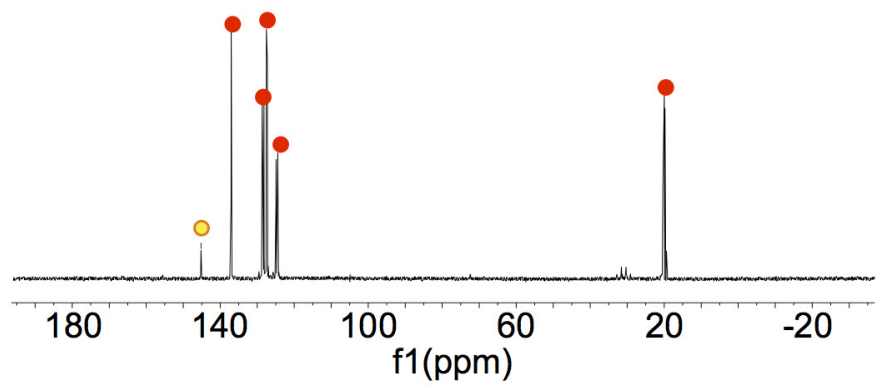

d

$\times 10^{3} 3$

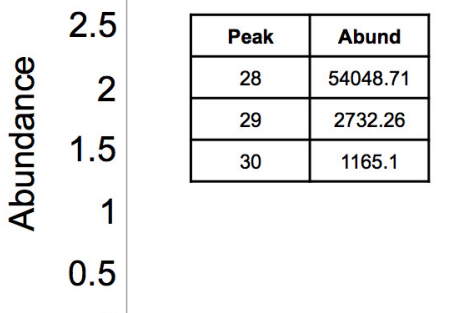

$\begin{array}{lllllllllllll}22 & 23 & 24 & 25 & 26 & 27 & 28 & 29 & 30 & 31 & 32 & 33 & 34\end{array}$ $\mathrm{m} / \mathrm{z}$

${ }^{14} \mathrm{~N}^{15} \mathrm{~N}$ and ${ }^{15} \mathrm{~N}_{2}$ with $m / z=29$ and 30 , respectively. The peak at $m / z=28$ arises from ${ }^{14} \mathrm{~N}_{2}$ and CO. ${ }^{14} \mathrm{~N}^{15} \mathrm{~N}$ and ${ }^{14} \mathrm{~N}_{2}$ arise from nitride/ $\mathrm{N}_{2}$ scrambling during the synthesis of $\mathbf{3}$. The inset details the measured abundance (intensity) for each peak. In a-c, symbols on peaks show assignments (see key at top). 


\section{RESEARCH LETTER}
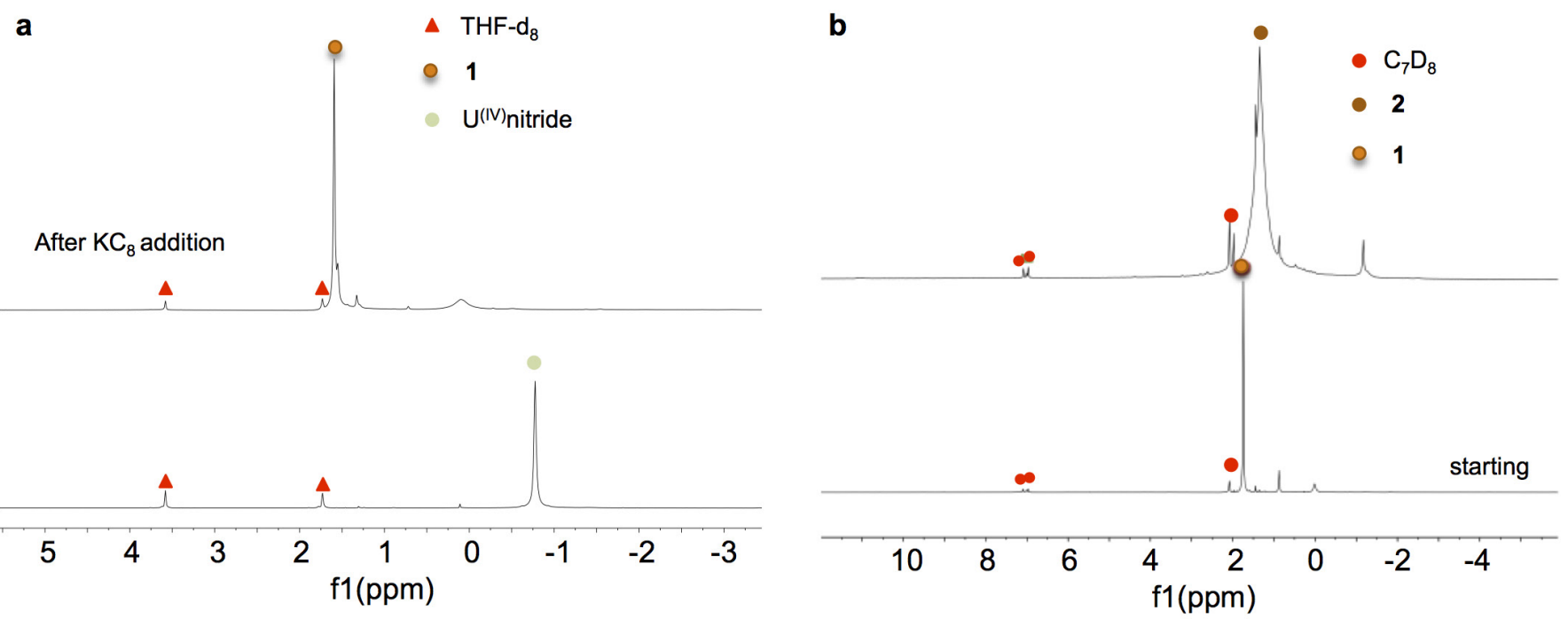

c

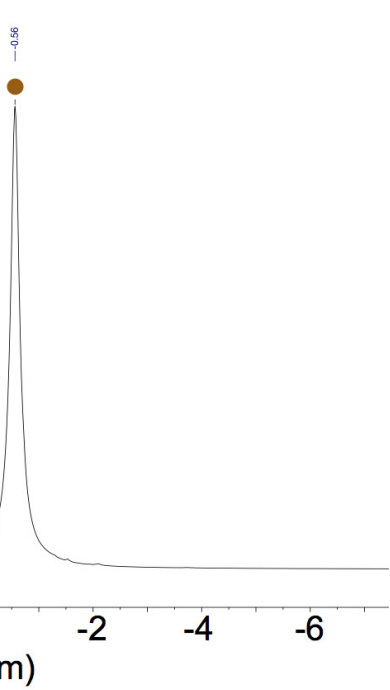

Extended Data Figure 7 Summary of ${ }^{1} \mathrm{H}$ NMR data for 1, 2 and 3. a, ${ }^{1} \mathrm{H}$ NMR spectra $\left(400 \mathrm{MHz}, \mathrm{THF}-\mathrm{d}_{8}, 298 \mathrm{~K}\right)$ of $\left[\mathrm{Cs}\left\{\left[\mathrm{U}\left(\mathrm{OSi}\left(\mathrm{O}^{t} \mathrm{Bu}\right)_{3}\right)_{3}\right]_{2}(\mu-\mathrm{N})\right\}\right]$ before (bottom) and after (top) addition of excess $\mathrm{KC}_{8}$ to yield to $\mathbf{1}$. $\mathbf{b},{ }^{1} \mathrm{H}$ NMR spectra ( $400 \mathrm{MHz}, \mathrm{C}_{7} \mathrm{D}_{8}, 298 \mathrm{~K}$ ) of the crude mixture before (bottom)

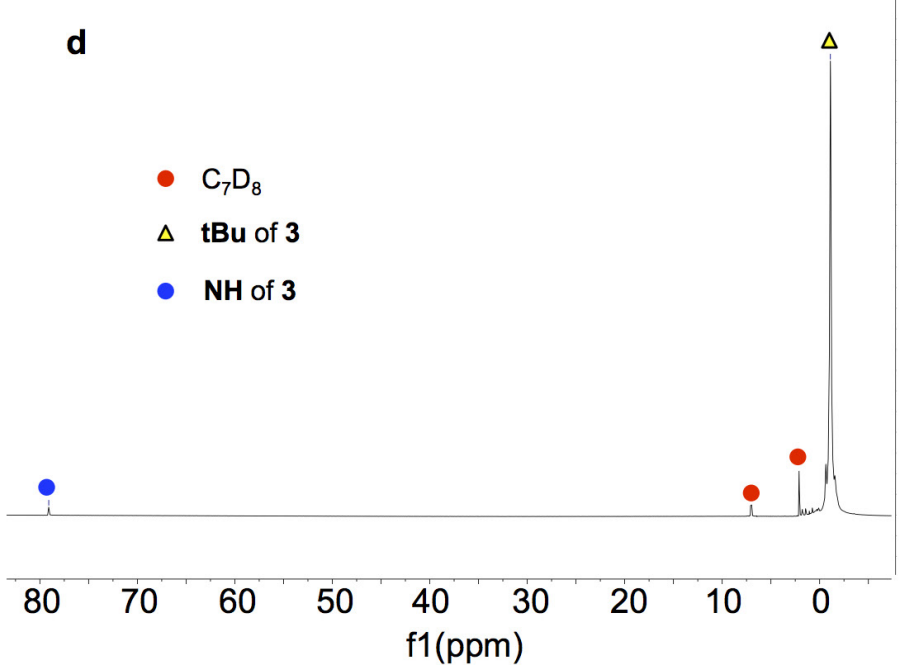

and after (top) addition of $\mathrm{N}_{2}$ to complex 1. c, ${ }^{1} \mathrm{H}$ NMR spectrum $(400 \mathrm{MHz}$, THF- $\mathrm{d}_{8}, 298 \mathrm{~K}$ ) of crystals of $\mathbf{2}$. d, ${ }^{1} \mathrm{H}$ NMR spectrum $\left(400 \mathrm{MHz}, \mathrm{C}_{7} \mathrm{D}_{8}\right.$, $298 \mathrm{~K}$ ) of crystals of complex 3. In each panel, symbols on peaks show assignments (see key at top). 
a

- $\mathrm{C}_{7} \mathrm{D}_{8}$

$\Delta$ New product

$\Delta \quad \mathrm{t} B u$ of 3
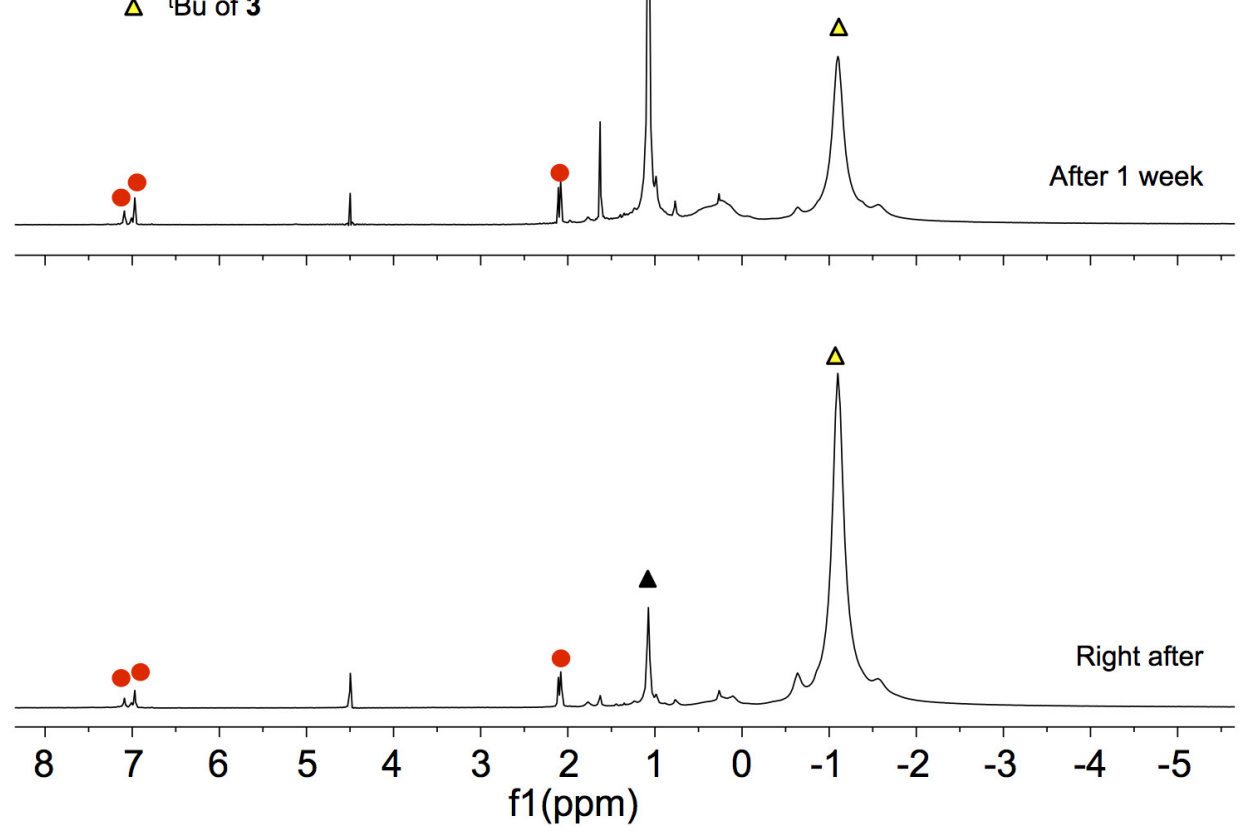

b

$\left[\mathrm{K}_{2}\left\{\left[\mathrm{U}\left(\mathrm{OSi}\left(\mathrm{O}^{\mathrm{tBu}}\right)_{3}\right)_{3}\right]_{2}(\mu-\mathrm{NH})(\mu-\mathrm{NCO})_{2}\right\}\right]$

C

$\mathrm{C}_{7} \mathrm{D}_{8}$
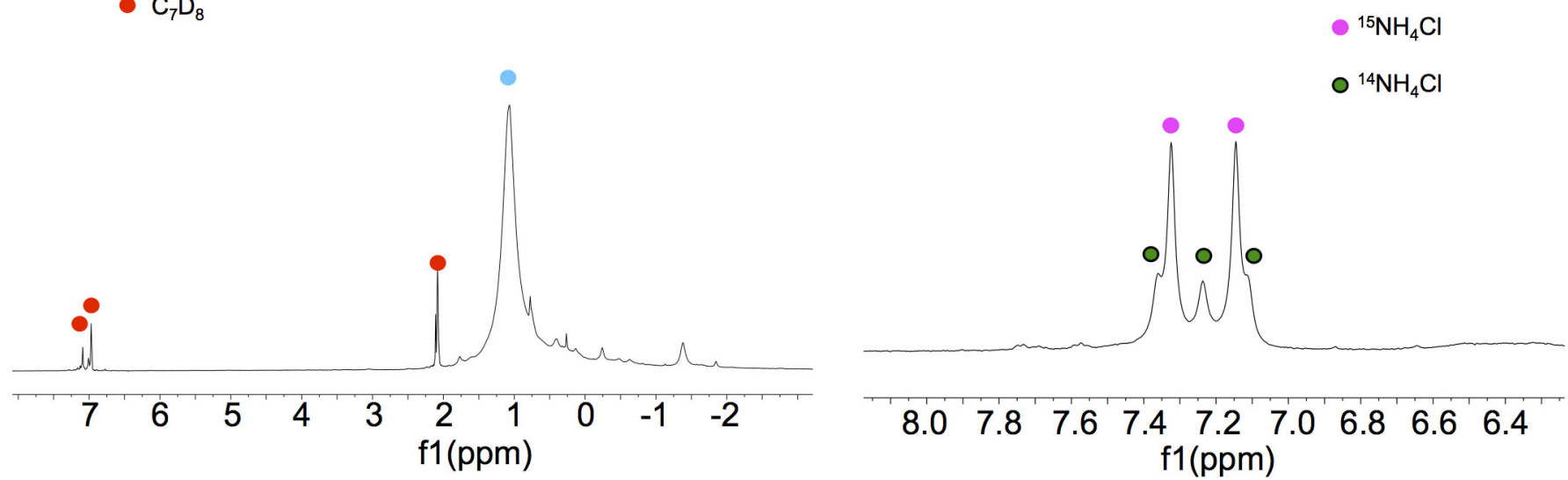

Extended Data Figure 8 Additional reactivity of 3 and 6. a, ${ }^{1} \mathrm{H}$ NMR spectra $\left(400 \mathrm{MHz}, \mathrm{C}_{7} \mathrm{D}_{8}, 298 \mathrm{~K}\right)$ of the crude reaction mixture after reaction of 3 with $\mathrm{H}_{2}(1 \mathrm{~atm})$ at room temperature for 1 week leading to a new product (top; bottom, immediately after introduction of $\mathrm{H}_{2}$ ). $\mathbf{b},{ }^{1} \mathrm{H}$ NMR spectrum $\left(400 \mathrm{MHz}, \mathrm{C}_{7} \mathrm{D}_{8}, 298 \mathrm{~K}\right)$ of the crude reaction mixture

after addition of 100 equiv. of $\mathrm{CO}$ to 3 . The chemical shift of the only product (labelled with a blue dot) is 1.08 p.p.m., very close to the chemical shift of complex 5. c, ${ }^{1} \mathrm{H}$ NMR spectrum $\left(400 \mathrm{MHz}\right.$, DMSO-d $\left.\mathrm{d}_{6}, 298 \mathrm{~K}\right)$ of the white precipitate formed after addition of excess $\mathrm{PyHCl}$ (20 equiv.) to ${ }^{15} \mathrm{~N}-6$. In each panel, symbols on peaks show assignments (see key at top). 


\section{RESEARCH LETTER}

Extended Data Table 1 | Crystallographic data of 1,2 and 3.toluene

\begin{tabular}{|c|c|c|c|}
\hline & 1 & 2 & 3.Toluene \\
\hline Formula & $\mathrm{C}_{72} \mathrm{H}_{162} \mathrm{~K}_{3} \mathrm{NO}_{24} \mathrm{Si}_{6} \mathrm{U}_{2}$ & $\mathrm{C}_{72} \mathrm{H}_{162} \mathrm{~K}_{3} \mathrm{~N}_{3} \mathrm{O}_{24} \mathrm{Si}_{6} \mathrm{U}_{2}$ & $\mathrm{C}_{79} \mathrm{H}_{171} \mathrm{~K}_{2} \mathrm{~N}_{3} \mathrm{O}_{24} \mathrm{Si}_{6} \mathrm{U}_{2}$ \\
\hline Crystal size $(\mathrm{mm})$ & $0.402 \times 0.111 \times 0.046$ & $0.20 \times 0.15 \times 0.10$ & $0.724 \times 0.487 \times 0.308$ \\
\hline cryst syst & Monoclinic & Trigonal & Triclinic \\
\hline space group & $\mathrm{C} 2 / \mathrm{c}$ & $\mathrm{R}-3$ & $P-1$ \\
\hline volume $\left(\AA^{3}\right)$ & $23766(5)$ & $16076.0(5)$ & $5792.02(17)$ \\
\hline $\mathrm{a}(\AA)$ & $56.507(9)$ & $23.8684(3)$ & $14.21015(19)$ \\
\hline $\mathrm{b}(\AA)$ & $14.4927(15)$ & $23.8684(3)$ & $17.5116(3)$ \\
\hline$c(\AA)$ & $29.069(3)$ & $32.5838(7)$ & $25.4916(4)$ \\
\hline$\alpha(\operatorname{deg})$ & 90 & 90 & $79.0803(14)$ \\
\hline$\beta$ (deg) & $93.331(10)$ & 90 & $88.6143(12)$ \\
\hline$Y($ deg $)$ & 90 & 120 & $68.5980(14)$ \\
\hline Z & 8 & 6 & 2 \\
\hline $\begin{array}{l}\text { formula weight } \\
\qquad(\mathrm{g} / \mathrm{mol})\end{array}$ & 2187.92 & 2215.95 & 2269.98 \\
\hline density $\left(\mathrm{g} \mathrm{cm}^{-3}\right)$ & 1.223 & 1.373 & 1.302 \\
\hline $\begin{array}{l}\text { absorption coeff } \\
\qquad\left(\mathrm{mm}^{-1}\right)\end{array}$ & 2.940 & 10.615 & 9.518 \\
\hline$F(000)$ & 8944 & 6792 & 2328 \\
\hline temp $(K)$ & $100(2)$ & $140.00(13)$ & $140.00(10)$ \\
\hline total refl & 124838 & 40364 & 43331 \\
\hline (- & 21850 & 7339 & 23323 \\
\hline uाingue & {$[R($ int $)=0.0946]$} & {$[R($ int $)=0.0409]$} & {$[R($ int $)=0.0405]$} \\
\hline Final $R$ indices [I > & $R_{1}=0.1066$ & $R_{1}=0.0450$ & $R_{1}=0.0514$ \\
\hline $2 \sigma(I)]$ & $w R_{2}=0.2327$ & $w R_{2}=0.1091$ & $w R_{2}=0.1345$ \\
\hline $\begin{array}{l}\text { Largest diff. peak } \\
\text { and hole }\left(e . \AA^{-3}\right)\end{array}$ & 2.638 and -2.276 & 2.646 and -3.263 & 4.056 and -4.974 \\
\hline GOF & 1.150 & 1.026 & 1.038 \\
\hline
\end{tabular}

'Cryst syst', crystal system; 'refl', reflections; $F(000)$, structure factor evaluated in the zeroth-order case, $h=k=I=0 ; R$ (int) $=\sum \mid F_{0}^{2}-F_{0}^{2}($ mean $) \mid / \sum\left[F_{0}^{2}\right] ; I$, measured intensities; 'Largest diff. peak and hole', maximum and minimum electron density found in the final Fourier difference map; GOF, goodness of fit $\left(=\left\{\sum\left[w\left(F_{0}^{2}-F_{\mathrm{c}}^{2}\right)^{2}\right] /(n-p)\right\} 1 / 2\right.$, where $n$ is the number of reflections and $p$ is the total number of parameters refined). 
Extended Data Table 2 | Crystallographic data of 4, 5.THF and 6

\begin{tabular}{|c|c|c|c|}
\hline & 4 & 5.THF & 6 \\
\hline Formula & $\mathrm{C}_{72} \mathrm{H}_{164} \mathrm{ClK}_{2} \mathrm{~N}_{2} \mathrm{O}_{24} \mathrm{Si}_{6} \mathrm{U}_{2}$ & $\mathrm{C}_{78} \mathrm{H}_{170} \mathrm{~K}_{2} \mathrm{~N}_{2} \mathrm{O}_{28} \mathrm{Si}_{6} \mathrm{U}_{2}$ & $\mathrm{C}_{73} \mathrm{H}_{163} \mathrm{~K}_{2} \mathrm{~N}_{2} \mathrm{O}_{25} \mathrm{Si}_{6} \mathrm{U}_{2}$ \\
\hline Crystal size (mm) & $0.205 \times 0.191 \times 0.109$ & $0.38 \times 0.33 \times 0.27$ & $0.585 \times 0.463 \times 0.382$ \\
\hline cryst syst & Monoclinic & Monoclinic & Monoclinic \\
\hline space group & $\mathrm{P} 22_{1}$ & $\mathrm{C} 2 / \mathrm{c}$ & $\mathrm{P} 22_{1}$ \\
\hline volume $\left(\AA^{3}\right)$ & $5550.2(2)$ & $23761.0(10)$ & $5584.7(3)$ \\
\hline a $(\AA)$ & $13.9073(3)$ & $49.0711(15)$ & $13.9643(4)$ \\
\hline $\mathrm{b}(\AA)$ & $18.2458(4)$ & $18.0309(6)$ & $18.1361(5)$ \\
\hline$c(\AA)$ & $21.9160(5)$ & $26.9338(6)$ & $22.0812(6)$ \\
\hline$\alpha(\mathrm{deg})$ & 90 & 90 & 90 \\
\hline$\beta$ (deg) & $93.603(2)$ & $94.389(2)$ & $92.980(2)$ \\
\hline Y (deg) & 90 & 90 & 90 \\
\hline$z$ & 2 & 8 & 2 \\
\hline $\begin{array}{l}\text { formula weight } \\
\qquad(\mathrm{g} / \mathrm{mol})\end{array}$ & 2200.29 & 2306.95 & 2191.84 \\
\hline density $\left(\mathrm{g} \mathrm{cm}^{-3}\right)$ & 1.317 & 1.290 & 1.303 \\
\hline $\begin{array}{l}\text { absorption coeff } \\
\qquad\left(\mathrm{mm}^{-1}\right)\end{array}$ & 10.129 & 9.31 & 3.092 \\
\hline$F(000)$ & 2250 & 9456 & 2242 \\
\hline temp $(\mathrm{K})$ & $100.01(10)$ & $140.0(1)$ & $140.09(13)$ \\
\hline total refl & 42431 & 79798 & 83917 \\
\hline \multirow{2}{*}{ unique refl $[R$ (int)] } & 20626 & 24371 & 26650 \\
\hline & {$[R($ int $)=0.0557]$} & {$[R($ int $)=0.071]$} & {$[R(\mathrm{int})=0.0439]$} \\
\hline Final $R$ indices [ $\mathrm{l}>$ & $\mathrm{R}_{1}=0.0503$ & $R_{1}=0.0616$ & $\mathrm{R}_{1}=0.0471$ \\
\hline $2 \sigma(I)]$ & $\mathrm{wR}_{2}=0.1274$ & $\mathrm{wR}_{2}=0.1531$ & $\mathrm{wR}_{2}=0.1084$ \\
\hline $\begin{array}{l}\text { Largest diff. peak } \\
\text { and hole }\left(\mathrm{e} . \AA^{-3}\right)\end{array}$ & 3.506 and -1.612 & 3.69 and -1.69 & 2.191 and -1.246 \\
\hline GOF & 1.032 & 1.071 & 1.030 \\
\hline
\end{tabular}

